\title{
APPLICATION OF LEAN CONSTRUCTION MANAGEMENT IN DELAYS IN REAL ESTATE CONSTRUCTION PROJECTS
}

\author{
Shivendra Vikram Singh \\ Department of Civil \\ J.S. UNIVERSITY, SHIKOHABAD, U.P.
}

Abstract - Throughout the years, there have been many investigations of postponement in development, and this kind of study keeps on being well known in development administration inquire about. A combination and basic assessment of defer studies in creating nations uncovers that poor venture administration is one of the fundamental driver of postponement. Be that as it may, regardless of huge agreement, most distributed reviews miss the mark concerning giving clear suggestions to the change of venture administration hone.

In this review, a detail writing audits were completed for the distinguishing proof of postpones considers development ventures. In view of this, ninety (90) components were recognized. The aggregate 90 defer components were arranged in 9 noteworthy classes. Utilizing these components different polls were set up on the points like (i) impacts of each defers figure, (ii) recurrence of each postpone elements, and (iii) seriousness of each postpone consider. With the assistance of writing surveys, polls were likewise arranged for (i) impacts of development postponements and (ii) techniques for limiting development delays.

For the gathering of tests through polls, private development activities were considered. These polls were disseminated among 340 private development ventures. Out of 350, 275 reactions were accurately topped off though 75 reactions were deficient. The 280 reactions were considered for the review purposes.

This information was classified and broke down to decide the Relative Importance Index (RII), Frequency Index (FI), Severity Index (SI) and Risk Index (RI). At that point the Overall Index (OI) was registered. In light of the OI, the positioning of postpones components were completed. The positioning aided in the assurance of top defers considers private development extends in India. The impacts of development postponements were investigated in view of RII to discover the rank of defer impacts. The techniques for limiting development postponements were likewise evaluated utilizing RII.

Endeavors have been made to survey Toyota Way hones inside land development firms. The quantitative information traces the norm of the Toyota Way-styled hones executed in the land development industry, and also the degree to which these properties were seen. The outcomes demonstrated that all the significant properties got from the Toyota Way model were valued by the respondents, yet a few qualities miss the mark regarding usage.

\section{INTRODUCTION}

The delay problem in the real estate construction industry is a worldwide phenomenon. Delays occur in real estate construction projects, either simple or complex. In construction, delay can be defined as the extension of time in the completion of project. In short delay means failure to complete project in targeted time \& budgeted cost as agreed in contract. The occurrence of delay may concurrently with other delays and all of them can impact the project completion date. However, many real estate projects experience extensive delays and thereby exceed initial time and cost estimates. Construction delay is considered to be one of the recurring problems in the construction industry and it has an adverse effect on project success in terms of time, cost and quality.

Real estate construction industries are growing in all over world. In India, time and cost overruns have been identified as the most important factors responsible for abandonment and contractor's failure. Although the Indian real estate construction industry has gained far more importance in recent times because of opening up of Indian markets and the arrival of megaprojects for infrastructure development, the performance of Indian construction projects. A study conducted by Infrastructure and Project Monitoring Division of Ministry of Statistics and Programme Implementation (http://www.mospi.nic.in) reports that out of 546 central sector projects (which are of order of more than $\$ 4.25$ million) Costing around $\$ 45$ trillion and average project duration of 7 to 8 years, about $40 \%$ are behind schedule and the delay ranges from 1 to 252 months.

The schedule overrun in percentage terms as on December 2003 was reported to be $40.23 \%$ while the figure for the same as on December 2004 was reported to be $40 \%$ (Iyer and Jha, 2006). 
Delay gives increase to disturbance of work and loss of productivity, late completion of project increased time related costs, and third party claims and abandonment or termination of contract.

Construction is the second largest economic activity after agriculture, and has contributed around 6.2 to $9 \%$ of India's GDP over the past five years while registering 8.5 to $10 \%$ growth per annum. The investments made in construction were reported to be close to USD 55 billion in 2008 with persistent growth pattern expected for much of the next decade. Contribution of the industry in terms of employment is also significant providing 31.46 million jobs; with about 1.35 million engineering jobs in 2008-2009. As per government data, the demand for construction manpower is projected to grow at a consistent pace of $8 \%-9 \%$, thereby resulting in an annual addition of around 2.52 million jobs to the existing stock with approximately 115,000 new engineering jobs being added annually.

\section{LITRATURE REVIEW}

In most construction projects there is often delays happen it will simple or complex. In construction, delay could be defined as the time overrun either beyond the contract date or beyond the date that the parties agreed upon for delivery of project, (Assaf and Al-Hejji, 2006). A project consists of a collection of activities. The delays activities can cause delays in the completion of the project. Delay analysis is used to determine the cause(s) of the delay and to know whether project needs extension or not. An extension of time relieves the contractor from the liability for damages Lowsley and Linnett et al. (2006). The analysis of delays in construction projects is difficult and complicated because of the large number of individual activities that have to be dealt with, even for a relatively simple project. A medium-sized project may consist of hundreds of activities, many of which may take place at different times and with different durations than originally planned Shi et al. (2001). Some activities may be delayed or accelerated, and such changes may partially or fully, or may not, affect the project completion date. In the study of Alaghbari et al. (2007), delay is generally acknowledged as the most common, costly, complex and risky problem encountered in construction projects. Majid et al. (2006) stated that delays can be minimized when their causes are identified. Identification of the factors that contributed to the causes of delays has been studied by numerous researchers in several countries. Delay is a situation when the contractor, consultant, and client jointly or severally contributed to the non-completion of the project within the original or the stipulated or agreed contract period. Because of the overriding importance of time for both the Owner (in terms of performance) and the Contractor (in terms of money), it is the source of frequent disputes and claims leading to lawsuits.

Table 2.1 Major causes of delay found by different researchers in different countries

\begin{tabular}{|c|c|c|c|}
\hline S.No & Researchers & Country & $\begin{array}{l}\text { Major cause of } \\
\text { delay }\end{array}$ \\
\hline 1 & $\begin{array}{c}\text { Chan and } \\
\text { Kumaraswamy }\end{array}$ & $\begin{array}{l}\text { Hong } \\
\text { Kong }\end{array}$ & 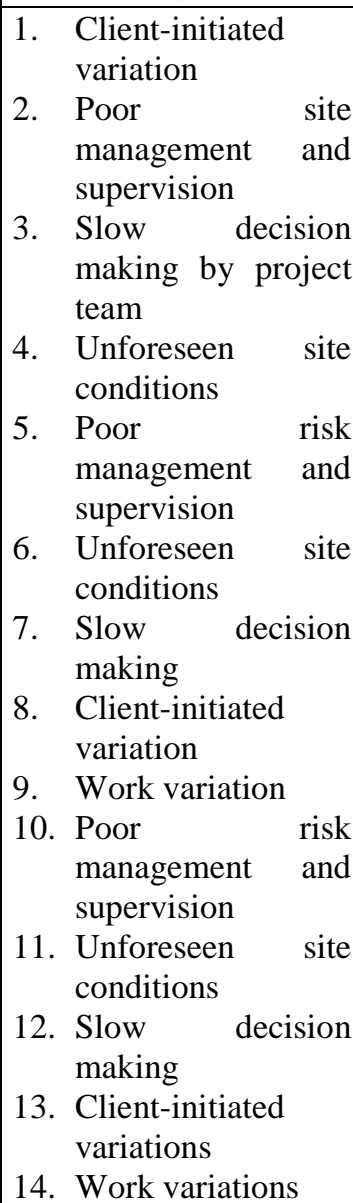 \\
\hline 2 & Ahmad & Florida & 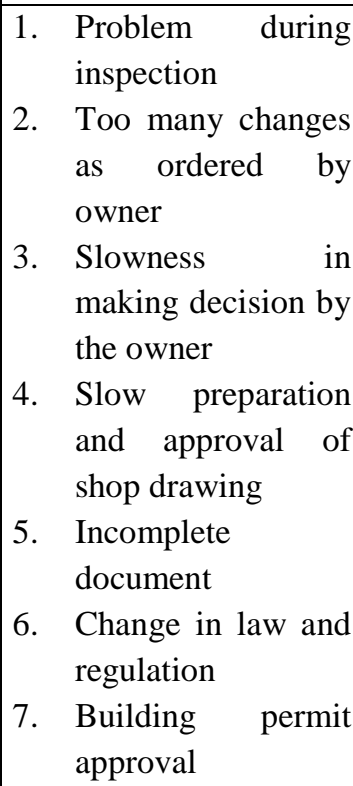 \\
\hline 3 & $\begin{array}{c}\text { Chan, W.M.D. } \\
\text { and }\end{array}$ & $\begin{array}{l}\text { Hong } \\
\text { Kong }\end{array}$ & $\begin{array}{ll}\text { 1. } & \text { Project scope } \\
\text { 2. } & \text { Complexity }\end{array}$ \\
\hline
\end{tabular}


International Journal of Engineering Applied Sciences and Technology, 2019

Vol. 4, Issue 3, ISSN No. 2455-2143, Pages 470-491

Published Online July 2019 in IJEAST (http://www.ijeast.com)

\begin{tabular}{|c|c|c|c|}
\hline & $\begin{array}{c}\text { 1.M.Kumaraswa } \\
\text { my }\end{array}$ & & $\begin{array}{ll}\text { 3. Environmental } \\
\text { factors } \\
\text { 4. } \\
\text { Management } \\
\text { attributes }\end{array}$ \\
\hline 4 & $\begin{array}{c}\text { Doloi,H., } \\
\text { Sawhney,andK. } \\
\text { C.Iyer }\end{array}$ & India & $\begin{array}{l}\text { 1. } \begin{array}{l}\text { Client's } \\
\text { interference } \\
\text { 2. Inefficient } \\
\text { construction } \\
\text { planning } \\
\text { 3. Delays in material } \\
\text { delivery by vendors } \\
\text { 4. Late availability of } \\
\text { drawings/designs } \\
\text { 5. Financial } \\
\text { constraints of the } \\
\text { contractor } \\
\text { An increase in the } \\
\text { 5cope of work } \\
\text { 7. Obtaining } \\
\text { permissions from } \\
\text { local authorities } \\
\text { 8. Lack of } \\
\text { commitment } \\
\text { 9. Inefficient site } \\
\text { management } \\
\text { 10. Poor } \\
\text { coordination } \\
\text { 11. Improper planning } \\
\text { 12. Lack of clarity in } \\
\text { projects scope } \\
\text { communication } \\
\text { contract }\end{array} \\
\text { 13. }\end{array}$ \\
\hline 5 & $\begin{array}{c}\text { Iyer, K.C., N.B. } \\
\text { Chaphalkar and } \\
\text { G.A. Joshi }\end{array}$ & India & $\begin{array}{l}\text { 1. Several factors , } \\
\text { categorized as } \\
\text { excusable and non- } \\
\text { excusable }\end{array}$ \\
\hline
\end{tabular}

\begin{tabular}{|c|c|c|c|}
\hline 6 & $\begin{array}{r}\text { Frimpong et al } \\
\text { (2003) }\end{array}$ & Ghana & \begin{tabular}{|l} 
1. \\
2. $\begin{array}{l}\text { Minancial problem } \\
\text { the scope of }\end{array}$ \\
projects \\
3. $\begin{array}{l}\text { Monthly payment } \\
\text { difficulties from }\end{array}$ \\
agencies \\
4. $\begin{array}{l}\text { Poor contractor } \\
\text { management }\end{array}$ \\
5. $\begin{array}{l}\text { Material } \\
\text { procurement }\end{array}$ \\
6. $\begin{array}{l}\text { Poor technical } \\
\text { performance }\end{array}$ \\
7. $\begin{array}{l}\text { Escalation } \\
\text { material prices of }\end{array}$
\end{tabular} \\
\hline 7 & $\begin{array}{c}\text { Frank D.K. et } \\
\text { al.(2010) }\end{array}$ & Ghana & $\begin{array}{ll}\text { 1. } & \text { Scheduling } \\
\text { 2. } & \text { Controlling } \\
\text { 3. } & \text { Honouring } \\
& \text { payments } \\
& \text { certificates } \\
\text { 4. } & \text { Difficulty in } \\
& \text { accessing credit } \\
& \text { and fluctuations in } \\
& \text { prices }\end{array}$ \\
\hline 8 & $\begin{array}{r}\text { rake MacDonald } \\
\text { (2011) }\end{array}$ & India & 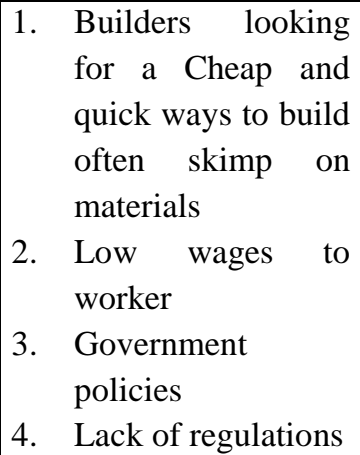 \\
\hline 9 & $\begin{array}{r}\text { Kaming el } \\
\text { at(1997) }\end{array}$ & $\begin{array}{c}\text { Indonesi } \\
\mathrm{a}\end{array}$ & \begin{tabular}{|ll} 
1. & $\begin{array}{l}\text { Inaccurate material } \\
\text { estimation }\end{array}$ \\
2. & $\begin{array}{l}\text { Degree } \\
\text { complexity }\end{array}$ \\
3. & Design changes \\
4. & Poor labor \\
productivity \\
5. & Inadequate \\
planning \\
6. & Resources shortage
\end{tabular} \\
\hline
\end{tabular}




\section{International Journal of Engineering Applied Sciences and Technology, 2019 \\ Vol. 4, Issue 3, ISSN No. 2455-2143, Pages 470-491 \\ Published Online July 2019 in IJEAST (http://www.ijeast.com)}

\section{PROPOSED ALGORITHM}

\section{Procedure DESIGN}

In this study, based on literature review, different delay factors were identified. The ninety (90) different delay factors were found and categorized into nine (9) major categories. Then, the questionnaires were distributed among 340 highly experienced construction professionals. Out of which, 280 responses were received. These data were used for the analysis of relative importance index (RII), frequency index (FI), severity index (SI), risk index (RI) and overall index (OII). The data collected for the various effects of construction delays were analyzed for the determination of relative importance index (RII).

\section{Preparation of questionnaire}

For preparation of questionnaire, detailed literature review were carried out. The literature review data were used for finding out the frequency of occurrence of each delay factor. The frequency studies helped in identifying the major construction delay factor. Based on this, 99 delay factors were considered in questionnaire.

\section{Delay factors}

The details of delay factors and their categorization are as under:

(1) Lack of experience of consultant in construction projects;

(2) Conflicts between consultant person and design engineer;

(3) Delay in approving major changes in work by consultant;

(4) Delay in inspection and testing; (5) Inaccuracy in site investigation; (6) Inadequate project management assistance; (7) Late review and approval of design documents; (8) Poor communication and coordination between owner and contractor; (9) Frequent change of subcontractors; (10) Inadequate contractor experience; (11) Inappropriate construction methods; (12) Incompetent project team; (13) Ineffective project planning and scheduling; (14) Obsolete technology;(15) Poor communication and coordination between owner and consultant; (16) Poor site management and supervision; (17) Rework due to errors; (18) Unreliable subcontractors; (19) Inadequate site investigation; (20) Inappropriate contractor's policies; (21) Poor financial control on site; (22) Complexity of project design; (23) Design changes by owner or his agent during construction; (24) Design errors and omissions made by designers; (25) Insufficient data collection and survey before design; (26) Lack of design team experience in construction projects; (27) Mistakes and delays in producing design documents; (28) Misunderstanding of owner's requirements by design engineer; (29) Poor use of advanced engineering design software; (30) Unclear and inadequate details in drawings; (31) Incomplete project design; (32) Defective design made by designers; (33) Equipment allocation problem; (34) Frequent equipment breakdowns; (35) Improper equipment; (36) Inadequate modern equipment; (37) Low efficiency of equipment; (38) Shortage of equipment; (39) Slow mobilization of equipment; (40) Accidents during construction; (41) Changes in government regulations and laws; (42) Different tactics patterns for bribes; (43) Delay in obtaining permits from municipality; (44) Delay in performing final inspection and certification by third party; (45) Delay in providing services from utilities (water, electricity, etc.); (46) Global financial crisis; (47) Loss of time by traffic control and restriction at job site; (48) Sudden failures actions; (49) Price fluctuations; (50) Problem with neighbors; (51) Slow site clearance; (52) Unexpected surface \& subsurface conditions (soil, water table, etc.); (53) Unfavorable weather conditions; (54) Inadequate production of raw material in the country; (55) Inappropriate government policies; (56) Thefts done on site; (57) Absenteeism; (58) Low motivation and morale of labour; (59) Low productivity of labour; (60) Personal conflicts among labour; (61) Shortage of labour; (62) Slow mobilization of labour; (63) Labour strikes due to revolutions; (64) Unqualified/inadequate experienced labour; (65) Labour injuries on site; (66) Changes in material types and specifications during construction; (67) Damage of sorted materials; (68) Delay in manufacturing materials; (69) Escalation of material prices; (70) Late delivery of materials; (71) Poor procurement of construction materials; (72) Poor quality of construction materials; (73) Shortage of construction materials; (74) Unreliable suppliers; (75) Change orders; (76) Conflicts between joint-ownership; (77) Delay in approving design documents; (78) Delay in progress payments (Funding problems); (79) Lack of capable representative; (80) Lack of owner experience in construction projects; (81) Lack of incentives for contractor to finish ahead of schedule; (82) Poor communication and coordination between consultant and contractor; (83) Slowness in decision making; (84) Suspension of work by owner; (85) Inadequate planning; (86) Mode of financing and payment for completed work; (87) Selecting inappropriate contractors; (88) Complexity of project (project type, project scale, . . ..etc.); (89) Inadequate definition of substantial completion; (90) Ineffective delay penalties.

\section{Table 2.1 Categorisation of delay factors in construction industries}

\begin{tabular}{|c|c|c|}
\hline $\begin{array}{c}\text { Sr. } \\
\text { No. }\end{array}$ & Category item & $\begin{array}{l}\text { Total no of } \\
\text { category Factors }\end{array}$ \\
\hline 1 & $\begin{array}{c}\text { Consultant Related } \\
\text { Factors Category }\end{array}$ & 8 \\
\hline 2 & $\begin{array}{c}\text { Contractor Related } \\
\text { Factors Category }\end{array}$ & 13 \\
\hline 3 & $\begin{array}{c}\text { Design Related Factors } \\
\text { Category }\end{array}$ & 17 \\
\hline 4 & $\begin{array}{c}\text { Equipment Related } \\
\text { Factors Category }\end{array}$ \\
\hline 5 & $\begin{array}{c}\text { External Related Factors } \\
\text { Category }\end{array}$ & 9 \\
\hline 6 & $\begin{array}{c}\text { Labour Related Factors } \\
\text { Category }\end{array}$ \\
\hline 7 & Material Related Factors & 7 \\
\hline
\end{tabular}


International Journal of Engineering Applied Sciences and Technology, 2019

Vol. 4, Issue 3, ISSN No. 2455-2143, Pages 470-491

Published Online July 2019 in IJEAST (http://www.ijeast.com)

\begin{tabular}{|c|c|c|}
\hline & Category & 14 \\
\hline 8 & $\begin{array}{c}\text { Owner Related Factors } \\
\text { Category }\end{array}$ & 4 \\
\hline 9 & $\begin{array}{c}\text { Project Related Factors } \\
\text { Category }\end{array}$ & 90 \\
\hline & Total & \\
\hline
\end{tabular}

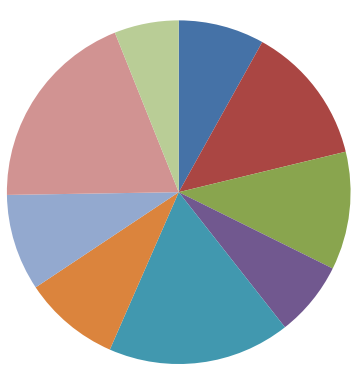

$$
\begin{aligned}
& \text { Consultant=8 } \\
& \text { Contractor=13 } \\
& \text { Design=11 } \\
& \text { Equipment=7 } \\
& \text { External=17 } \\
& \text { Labour=9 }
\end{aligned}
$$

Total $=90$

Figure 2.1 Total number of category factors

Table 2.2 Categorisation of responses of the questionnaires

\begin{tabular}{|c|c|c|}
\hline $\begin{array}{c}\text { Years of } \\
\text { experience }\end{array}$ & $\begin{array}{c}\text { No. of } \\
\text { respondents }\end{array}$ & Percentage\% \\
\hline 1 to 5 years & 42 & 15.27 \\
\hline 5:10 Years & 58 & 21.09 \\
\hline 10:15 Years & 86 & 31.27 \\
\hline $\begin{array}{c}\text { Above 15 } \\
\text { Years }\end{array}$ & 89 & 32.36 \\
\hline Total & 275 & 100.00 \\
\hline
\end{tabular}

Table 2.3 Working experience of respondents

\begin{tabular}{|c|c|c|c|}
\hline ID & $\begin{array}{c}\text { Professional } \\
\text { cadre of } \\
\text { Respondents }\end{array}$ & $\begin{array}{c}\text { No. of } \\
\text { respondents }\end{array}$ & Percentage\% \\
\hline 1 & Owners & 4 & 1.45 \\
\hline 2 & Consultants & 20 & 7.27 \\
\hline 3 & Managers & 44 & 16.00 \\
\hline 4 & Engineers & 82 & 29.82 \\
\hline 5 & Contractors & 125 & 45.45 \\
\hline & Total & 275 & 100 \\
\hline
\end{tabular}

Figure 2.2 Respondent's response of the questionnaires

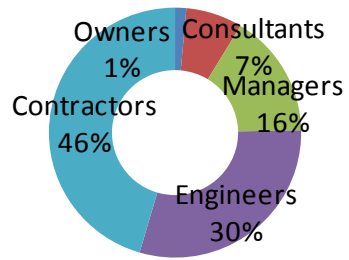

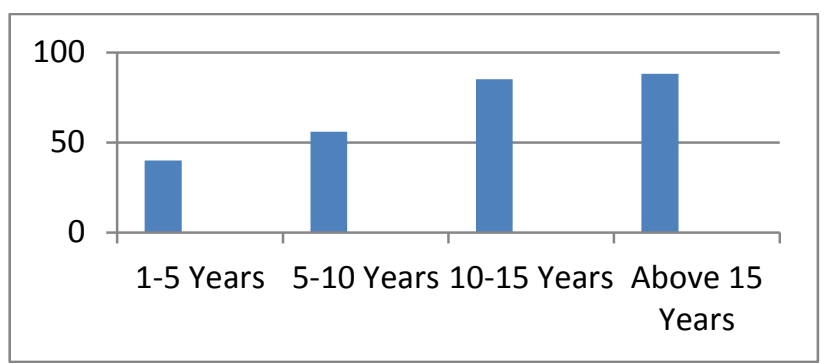

Figure 2.3 Graphical view of respondent's experience profile

Data collection techniques

Based on the literature reviews, it was found that researchers have carried out analysis on residential projects in different parts of the Uttar Pradesh. In India, very limited studies have been carried out on the residential projects. Therefore, the work on the residential projects was chosen for the study purpose.

Prepared questionnaire distribution and responses received

Questionnaires were mailed to respondents (Owners, Consultants, Managers, Engineers, and Contractors). Completed forms were requested to be mailed or faxed back to the researcher, and the response for this request was poor. Another approach of collecting data was used; subsequent visit to firms and work sites, most of data were collected by this method. Forms were given to respondents to complete, and completed forms were collected later. In many instances, forms were completed at the meeting; this method had the added benefit of making clarifications to respondents about questions in forms; it also gave a chance to the researcher to explore further project delay management practices and concerns. Over a period of six (6) months later, the researcher collected two hundred and seight (280) responses out of three hundred and forty (340) from the construction industries. That is rate of response was $82.35 \%$.

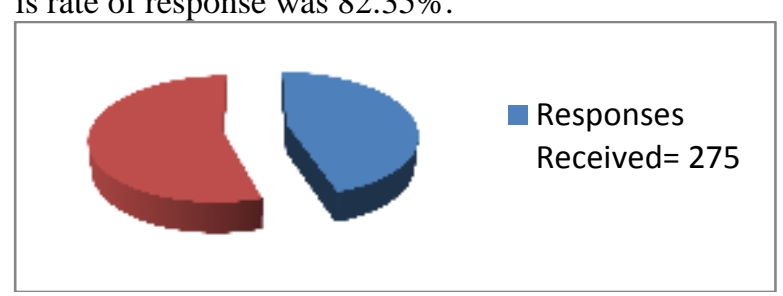

Figure 2.4 Questionnaire distribution and response

Analytical methods of data

The following indexes were used in analysis of data:

3.6.1Relative importance index

The RII was computed by Chan and Kumaraswamy (2002) using the following formula: 
[RII $] \mathrm{k}^{\wedge} \mathrm{i}(\%)=(1 \times(\mathrm{n} 1)+2 \times(\mathrm{n} 2)+3 \times(\mathrm{n} 3)+4 \times(\mathrm{n} 4)+5 \times(\mathrm{n} 5)) /(5 \times$ $(n 1+n 2+n 3+n 4+n 5)) \times 100$

Where $\left[\mathrm{RII} \rrbracket \_\mathrm{k}^{\wedge} \mathrm{i}(\%)\right.$ is the Relative Importance Index of each factor. $\mathrm{n} 1 ; \mathrm{n} 2 ; \mathrm{n} 3 ; \mathrm{n} 4$; and $\mathrm{n} 5$ are the numbers of each grouped respondents who selected: "1" representing very little effect; " 2 " representing little effect; " 3 " representing average effect; "4" representing high effect and "5" representing very high effect.

\section{Severity Index}

The SI was computed by Assaf and Hejji (2006) for the construction projects. They used the following formula:

Severity Index $(S . I \%)=\sum a(n / N) * 100 / 4$

where $\mathrm{a}=$ constant expressing weighting given to each response, which ranges from 0 for no influence up to 4 for very high; $\mathrm{n}=$ frequency of the responses; and $\mathrm{N}=$ total number of responses.

Accordingly, if all participants answer one cause to be no influence, then the severity index is 0 , meaning that this cause is not relevant and the last in rank. Conversely, if all answer very high influence, then the severity index is 100 , meaning that this cause is very highly relevant and is the first in rank.

\section{Frequency index}

The frequency index was calculated by Le- Hoai et al. (2008), The following formula was used in this analysis for the determination of frequency index of each delay factor.

\section{Frequency index $\left(\right.$ F.I \%) $=\sum \mathbf{a}(\mathbf{n} / \mathbf{N}) * 100 / 4$}

Where, a is constant expressing weighting given to each response (ranges from 1 rarely up to 4 for always), $\mathrm{n}$ is the frequency of the response, and $\mathrm{N}$ is the total no of responses.

\section{Risk index}

The risk index of each delay factor was calculated by the following formula:

\section{Risk index $($ RI \% $)=[$ F.I $(\%) *$ S.I. $(\%)] / 100$ \\ Overall Index}

The overall index of each delay factor was calculated by taking the mean of relative importance index, frequency index, severity index and risk index, which are as follows:

Overall Index $(\mathbf{O . I})=(\mathbf{R I I}+\mathrm{FI}+\mathrm{SI}+\mathrm{RI}) / \mathbf{4}$

Where RII is relative importance index, FI is frequency index, $\mathrm{Si}$ is severity index and RI is risk index and $\mathrm{OI}$ is overall index.

From this analysis, overall index of each delay factor was assessed for the ranking purpose.

\section{ANALYSIS OF DELAYS IN INDIAN REAL SECTOR CONSTRUCTION PROJECTS AND THEIR IMPACT ON OVERALL PROJECT PERFORMANCE}

A delay generally leads to social inconvenience and loss of capital and revenue, and to extreme affects, such on the national growth rate of country. It also suffers a loss of productivity, high disruption costs, and prolongation costs. Schedule delays are common in construction projects. Although many methods have been developed for analyzing and measuring schedule delays for construction projects. This thesis presents the Isolated Collapsed But-For (ICBF) method, an innovative delay analysis method and also earned value management is use to assess the project performance.

\section{Introduction}

Delays are one of the biggest constraints for construction firms working real estate to face. Due to the inherent risks and increasing complexity of modern real estate construction projects, delays and cost overruns have become common constraints in the industry. Delays can lead to many stereotypes i.e. disputes between owners and contractors leading to arbitration, increased costs, loss of productivity and revenue, and contract termination. In India, a study conducted by the Infrastructure and Project Monitoring Division of the Ministry of Statistics and Program Implementation in 2004 reported that out of 546 central sector projects costing about $\$ 45$ trillion, approximately $40 \%$ are behind schedule, with delays ranging from 1 to 252 months Iyer \& Jha et al.(2006). Researchers and practitioners have used many techniques to assess project delays and apportion delay responsibility among the parties involved. There are various methods that exist for schedule delay analysis. No one method is currently acceptable for all projects participants or suitable for all situations.

Arditi \& Pattanakitchamroom et al.(2006), while discussing how to select a delay analysis method, concluded that selecting a feasible analysis method depends on a variety of factors such as available information, time of analysis, methodology capabilities, and time, funds, and effort allocated for analysis. To recover the damage caused by delays, both the delays and the parties responsible for them should be identified. However, delay situations are complex in nature because multiple delays can occur concurrently and because they can be caused by more than one party, or by none of the principal parties. One delay may contribute to the formation of other delays Arditi \& Pattanakitchamroom et al.(2006). The analysis of these delays involves not only the calculation of the delay time but also the identification of the root causes and the responsibility for delays, Such an analysis therefore becomes a basis for the financial calculations that determine penalties or other damages to be assigned to the parties responsible for the delays.

\section{Methodology}

The study presents delay cause approach to collect the causes of delays, impacts of delay associated with an activity on succeeding activities, and to analyze the effect of existing delays on overall project completion time. We have proposed implementation of the isolated collapse but-for analysis Yin \& Yang et al.(2009) in Indian real estate projects and also uses earned value management to assess the impacts of delays on approved project cost and time. 
Prior to delay analysis it is required to have and as planned schedule to define a contractor's original plan for performing its entire scope of work, as-built schedule reflects the actual succession of the events that happened during execution of the project, entitlement schedules consisting of either extended asplanned schedules (i.e. the as-planned schedule with certain classes of delays added) or collapsed as-built schedules (i.e. the as-built schedule with certain classes of delays removed), and lastly adjusted schedule for quantification and identification of impact of schedule variances on the project also it is useful in determining the effects of different types of delays on the project completion date. But in practice, most of the organizations working in real estate apply these four schedules. It is prior to mention that these are legally acceptable and vital for settlement of disputes.

\section{Liability calculation algorithm}

For each analysis scenario, Equation (1) determines anticipated project completion duration $\left(\right.$ Dur $_{i}{ }^{\text {base }}$ ), which is calculated by actual duration $\left(\right.$ Dur $_{i}{ }^{\text {act }}$ ) before an analysis timepoint plus as-planed duration $\left(\right.$ Dur $_{\mathrm{i}}{ }^{\text {plan }}$ ) for activities completed after the analysis time-point. For each analysis period, Equations (2) and (3) are the algorithms for determining project completion duration caused by the owner and contractor respectively. Dur ${ }_{i}{ }^{\text {own }}$ and $\operatorname{Dur}_{i}{ }^{\text {con }}$ are durations for which the owner and contractor are responsible, respectively; $\operatorname{Dur}_{i}{ }^{C D}, \operatorname{Dur}_{i}{ }^{N D}$ and Dur ${ }_{i}{ }^{E D}$ are the impacted durations caused by compensable delays, non-excusable delays and excusable delays respectively. In each analysis period, delay liability for the owner (Duty ${ }_{i}^{\text {own }}$ ) and contractor (Duty ${ }_{i}^{\text {con }}$ ) are calculated using an apportioned duration minus the total anticipated project completion duration, as in Equations (4) and (5). After determining the delay liability in each analysis scenario, the proposed method summarizes project delay liability for each contract party (Duty ${ }^{\text {own }}$ for the owner and Duty ${ }^{\text {con }}$ for the contractor) from all analyzed periods using Equations (6) and (7).

$$
\begin{aligned}
& \operatorname{Dur}_{i}{ }^{\text {base }}=\operatorname{Dur}_{i}^{\text {act }}+\text { Dur }_{i}^{\text {plan }} \\
& \operatorname{Dur}_{i}{ }^{\text {own }}=\operatorname{Dur}_{i}{ }^{\text {base }}+\left(\operatorname{Dur}_{i}{ }^{C D}+\operatorname{Dur}_{i}{ }^{\text {ED }}\right. \\
& \operatorname{Dur}_{i}{ }^{\text {con }}=\operatorname{Dur}_{i}^{\text {base }}+\operatorname{Dur}_{i}{ }^{\text {ND }} \\
& \text { Duty }_{i}{ }^{\text {own }}=\text { Dur }_{i}^{\text {own }}-\text { Dur }_{i}^{\text {base }} \\
& \text { Duty }_{i}{ }^{\text {con }}=\text { Dur }_{i}{ }^{\text {con }}-\text { Dur }_{i}{ }^{\text {base }} \\
& \text { Duty }^{\text {own }}=\sum \text { Duty }_{i}{ }^{\text {own }} \\
& \text { Duty }^{\text {con }}=\sum \text { Duty }_{i}{ }^{\text {con }}
\end{aligned}
$$

\section{Case study}

The existing land in and around Integral University campus, Lucknow is developing area because many real estate developers already initiate their projects for commercial and residential purposes. We have analyzed such real estate projects with budgeted cost of Rs. 1,00,00,000 (approx.) which are under-construction and time overrun. The general track record for timely completion is poor and cases of dispute are very popular (Real Estate Sector). Based on the available records and study, an illustrative case consists of different types of delays is prepared.

This illustrative case has ten activities and an original duration of 28 days. The project is completed in 43 days, with 15 days of project delays. Table 1 and 2 shows the as-planned and asbuilt schedule respectively. This study uses this case to demonstrate the functionality of delay cause approach, delay effect approach, Isolated Collapsed But-For (ICBF) method and Earned Value Management to solve delay related issues. Table 3 lists the start and finish dates for each delay event. This illustrative case has concurrent delays that happened with activities A-Band C - E.

Table 3.1 As-planned Schedule

\begin{tabular}{|c|c|c|c|c|c|}
\hline Activity & Duration & Start & Finish & $\begin{array}{c}\text { Preceding } \\
\text { Activity }\end{array}$ & $\begin{array}{c}\text { Succeeding } \\
\text { Activity }\end{array}$ \\
\hline A & 6d & 1 & 6 & & C \\
\hline B & $7 d$ & 1 & 7 & & D,E \\
\hline C & $9 d$ & 7 & 15 & A & F \\
\hline D & $5 d$ & 8 & 12 & B & G \\
\hline E & $12 d$ & 8 & 19 & B & H \\
\hline F & $7 d$ & 16 & 22 & C & I \\
\hline G & $4 d$ & 13 & 16 & D & \\
\hline H & $6 d$ & 20 & 25 & E & J \\
\hline I & 5d & 23 & 27 & F & \\
\hline J & $3 d$ & 26 & 28 & H & \\
\hline
\end{tabular}

Table 3.2 As-built Schedule

\begin{tabular}{|c|c|c|c|c|c|}
\hline Activity & Duration & Start & Finish & $\begin{array}{c}\text { Preceding } \\
\text { Activity }\end{array}$ & $\begin{array}{c}\text { Succeeding } \\
\text { Activity }\end{array}$ \\
\hline A & 10d & 1 & 10 & & C \\
\hline B & $11 \mathrm{~d}$ & 1 & 11 & & D,E \\
\hline C & $15 \mathrm{~d}$ & 11 & 25 & A & F \\
\hline D & 5d & 12 & 16 & B & G \\
\hline E & 18d & 12 & 29 & B & H \\
\hline F & 9d (1) & 26 & 34 & C & I \\
\hline G & 6d (2) & 17 & 22 & D & \\
\hline H & 9d (3) & 30 & 38 & E & J \\
\hline I & 8d (4) & 35 & 42 & F & \\
\hline J & 5d (5) & 39 & 43 & H & \\
\hline
\end{tabular}

Delay cause apprgach and its translation into delay effect In a test case ownef decided to change order work on working day 3 (working days denoted by WD further in study) and issued a change order on WD 4. The cause of delay was change order and of next compensable delays (denoted by CD further in study) is delay in making payments. On WD 7, contractor had re-performed defected work the next day and on WD 9, delay- cause is irregularity in inspection work. Similarly, the causes of delays in next succeeding activities are determined and added for forecasting project completion date. Non excusable delays (denoted by ND further in study) are due to the implementation of improper construction 


\section{International Journal of Engineering Applied Sciences and Technology, 2019 \\ Vol. 4, Issue 3, ISSN No. 2455-2143, Pages 470-491 \\ Published Online July 2019 in IJEAST (http://www.ijeast.com)}

methods. Excusable delays (denoted by ED further in study) are due to conflict between design engineer and contractor.

The delay-cause approach is then translated into delay-effect scenario to reflect delay effects on overall project completion date.

The delay-effect approach is premised on the basis that there is no 'delay' until the planned duration of an activity that has been affected by a delay has been exhausted. The delay-cause approach and delay-effect scenario are portrayed in figure 4.1 and figure 4.2 respectively. This approach aligns the delay causes with the effects, based on the available documentation, to understand both the cause and the effect of delay.

\section{Delay analysis using ICBF method}

Four analysis periods are determined which are as follows.

4.6.1 Analysis Period 1 (day 35 to day 43)

Activities $A$ to $G$ are Type 1, and maintain their actual start and finish dates. Activity $\mathrm{H}$ is type 2 and hence, is started on its actual start date with an adjusted duration of 8 days. Activities $I$ and $J$ are type 3. So, activities $I$ and $J$ are scheduled on their actual start date and maintain their asplanned duration. These manipulations form the baseline and determine the project will be completed on day 40. Firstly, CD and ED are assigned on the impacted activity. The durations of activities- H, I and $\mathrm{J}$ after analysis are 9 days (1 day delay), 6 days ( 1 day delay), 4 days ( 1 day delay) respectively. These activities start on their actual start dates or their predecessor's finish dates. After completing these manipulations, the project is completed on day 42 which indicates that owner deserved 2days delay $(42-40=2)$. Next, ND is assigned on the impacted activity and the durations of activities $\mathrm{H}, \mathrm{I}$ and $\mathrm{J}$ are 8 days $(0$ day delay), 7 days (2 days delay), 4 days (1 day delay) respectively. These manipulations indicate the project is completed on day 41. So, contractor deserved 1 day delay (41$40=1$ ).

Analysis period 2 (day 26 to day 34)

Activities, A, B, C, D and G are type 1 and maintain their actual start and finish dates; activity $\mathrm{E}$ is type 2 and activity $\mathrm{F}$ is type 3. Activity $\mathrm{H}$ is type 4 , maintains its adjusted duration in previous analysis period minus 2 days delay. Activities I and $\mathbf{J}$ are type 5 . This information concludes that day 38 is the target baseline for project completion. In considering owner liability, the project is completed on day 39. Therefore, owner deserved 1day delay (39-38=1). Here, contractor deserved no delay.

Analysis period 3 (day 11 to day 25) and analysis period 4 (day1 to day 10)

Similar to the process used in the previous two analysis periods, the baseline schedule of analysis period 3 is found to be day 32 and the owner deserved 3 days delay and contractor deserved 2 days delay. Finally, for analysis period 4 , the baseline schedule obtained by the ICBF method is the same as the as-planned schedule, in which the projects end on day 28. Here, both parties deserve 2-days delays.

Results
The ICBF method concludes that the contractor causes 5 day delay [owner has the responsibility of 10 day delay $(15-5=10)$ ] and the owner causes 8 day delay [the contractor has responsibility of 7 day delay $(15-8=7)]$. Therefore, the contractor would claim 3 days $(10-7=3)$ for compensation. In this test case, the summation of delay responsibilities caused by the contractor ( 7 days) and the owner (10 days) is 17 days. The concurrent delay ( 2 days on day 4 and 14) can be calculated by using the summation value of delay responsibilities caused by the contractor and the owner (17 days) minus total delay days (15 days). For each analysis period the causes of delays can be identified by the delay cause approach used previously in the study.

\section{Implementation of Earned Value Management in the delay analysis}

The budgeted cost of the project is Rs. 1, 00, 00,000. The project takes 28 days to complete $(3.6 \%$ of work to be completed per day). Per unit of work per day in percent represents ratio of percent completion of work per day and total units of work per day.

Per day expense is same for all days (Rs. 3, 57,143) and is equally distributed to each unit of work. For no working day (wholly or partially), an expense of Rs. 3, 57,143 is wasted.

At the end of day 10 , only $21.6 \%$ (12 units of work $* 1.8 \%$, 1.8 denotes percent completion of work per day $(3.6 \%)$ divided by two units of work per day) of total project work is completed at a total expense of Rs. 35, 71,430 (per day expense*10). The planned completion should have been $36 \%$ (percent completion of work per day (3.6\%) multiplied by 10 (WD)). The Budget at Completion (denoted by BAC) is Rs. 1, 00, 00,000 and Actual Cost is Rs. 35, 71,430. Planned Value (Rs. 36, 00,000) is planned completion of work in percent multiplied by BAC and Earned Value (Rs. 21, 60,000) is actual completion of work in percent multiplied by BAC.

Planned Value (0 delay) considers only units of work in computation while Earned Value shows the effect of delays on work progress. Therefore, the Earned Value is less than Planned Value.

The Cost Performance Index (CPI) is the ratio of Earned Value to Actual Cost and is 0.60 . This means that for every Rs. 1 spent, the project is producing only Rs. 0.60 in work.

The Schedule Performance Index (SPI) is the ratio of Earned Value to Planned Value and is 0.60. SPI shows that for every estimated hour of work, the project team is completing only 0.60 hour (approximately 36 minutes).

Since both CPI and SPI are less than one, the drawn interpretation is that the project is over budget and behind the schedule.

Risk management needs to kick-in. This case is in major trouble and corrective action needs to be taken. Both the contract parties should minimize the probability of delay occurrence in remaining activities so as to keep the project on schedule. 


\section{International Journal of Engineering Applied Sciences and Technology, 2019 \\ Vol. 4, Issue 3, ISSN No. 2455-2143, Pages 470-491 \\ Published Online July 2019 in IJEAST (http://www.ijeast.com)}

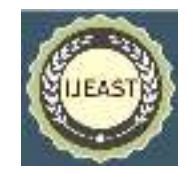

Similarly, at the end of day 25, it is analyzed how healthy the project is by computing CPI and SPI to record the influence of 14 days delay (wholly or partially) on the overall project performance. Project is completed $58.2 \%$ at a total expense of Rs. 89, 28,575, CPI is 0.65 and SPI is 0.64 which indicate that project is not under budget and is behind schedule.

\section{EARNED VALUE BASED LIABILITY CALCULATION ALGORITHM FOR SCHEDULE DELAYS IN CONSTRUCTION PROJECTS}

Construction Industry is growing globally with focus of authorities on development. With this growth there are certain constraints that prevent timely completion of project causing huge economic loss. If a project could not be delivered with a given time frame then the delay occurring is known as scheduled delay. The present study deals with study of delays on the basis of two factors i.e. delays caused by parties involved, cost of each delays. Work done will be useful for practitioners in case of arbitration matters by helping them to decide liabilities of all parties involved in an activity. Introduction

In India, construction projects could not be prevented from the complication of time overshoot, due to their proliferation and entanglement, probability of delays begins to be unexceptional which manifests delays in construction projects. Mathematically, construction delays are the function of time. Delay could be defined as the overshoot stretch post the committed epoch for which litigants are organized for accomplishing project work packages fortunately. The existence of delays enlarges and infects the as-planned schedule as contract may be aborted if time overshoots. Delays may induce supplemental costs, direct costs and indirect costs of numerous activities. It is indispensable to scrutinize delays and to ascertain a defendant accountable for delay contingency in exposition of large projects work packages. An ordinary ranged project consists of multiple activities; numerous of them might be executed inconsistently and unconventionally. Ahmad et. al. (2002) had said that if a construction project is running behind the schedule and is not able to meet deadline, hence there is a scheduled delay in project. This is the most commonly occurring reoccurring constraint being faced by construction in present scenario. Formerly inquisitors have endeavored to reconcile construction delays disputes by uncovering time overrun data acquired from as-planned and as-built schedules.

There are numerous approaches accessible to allocate delay accountability among the presupposed litigants but no one is undertaken forthwith for all variety of projects. Earlier studies suggested that more than $40 \%$ projects have been reported suffering from delay across country Iyer and Jha et al.(2005).

The two brackets in which delay can be grouped are delays during initiating and planning phase and the other is delay during executing phase of the project validity.

Delays during initiating and planning phase can be induced by Project Management Team (construction contracts type, project bidding and award types, improper time and resources estimation), Design Engineer (delay in producing and approving design documents), architect or consultant (delay in performing inspection and testing and in modifying the scope of work) and are referred as third party delays of planning phase. These delays are excusable and sole relief for third party delay is a time extension. Delays during executing phase can be caused by owner, contractor, labor, accidents, social and cultural factors, construction equipment's breakdown and failure, material shortages.

Three major classes can represent delays during execution phase namely, compensable delays, non-excusable delays and force majeure delays. Compensable delays can be provoked by the owner's side. Non-excusable delays can result from the contractor's own actions and/or inactions and are caused by the contractor's failure to implement proper construction methods, doing/performing work not acceptable by owner and to have skilled/experienced contractor staff. In this case, the contractor is entitled neither damages nor time extensions from the owner. Force majeure delays are forgivable delays arise coincidently when the contractor is retarded by circumstances which are unforeseen and unplanned to either the contractor or owner.

\section{Methodology development}

The study continues by amending the Isolated Collapsed but for Analysis (ICBF) for calculating affected time span due to existence of force majeure delays. An analytical process to ascertain the delays aftermath on dissimilar costs set is highlighted in figure5.1 in association with deduction of Earned Value Management build variables to assess project standing at various interims along the critical path.

Improvements in ICBF method

ICBF method Yang and Yin et al.(2009) includes excusable non compensable delays as delay liability to owner, does not include delays caused by the third party and determines only one type of concurrent delay i.e. delay caused by owner concurrent with delay caused by contractor within the critical path and excludes all other concurrent delays. Furthermore, changes in direct cost and indirect cost associated with an activity are not discussed. The modified isolated collapsed but-for method overcomes these drawbacks and determines all types of concurrent delays in the critical path, finds the delays caused by owner, contractor and third party separately with the determination of total concurrent delays and nonconcurrent delays in the critical path and determines the direct cost and indirect cost of an activity in working days and in delayed days caused by contractor, owner and third party.

The proposed method considers concurrent delays as delays caused by virtual party and determination of concurrent delays can be done as follows. Using as-built schedule the day(s) is investigated which consists of concurrent delays on the parallel critical activities.

For each analysis period, the modified ICBF method inserts the investigated concurrent delays either on first/last activity or on activity which affects the starting of last activity of any 


\section{International Journal of Engineering Applied Sciences and Technology, 2019 Vol. 4, Issue 3, ISSN No. 2455-2143, Pages 470-491 \\ Published Online July 2019 in IJEAST (http://www.ijeast.com)}

critical path. The impacted project completion day is identified and compared with the already formed new baseline. The difference between these two indicates total number of concurrent delays.

\section{Analytical process}

Initially, this proposed method determines the time wise longest path (critical path) considering as-built schedule. This method breaks the critical path into separate critical activities. The start day and finish day of each critical activity is considered as an analysis period. The mechanism is similar to what is given for ICBF method and is discussed as follows. The modified ICBF technique conducts delay scrutiny for three unconstrained perspectives; namely, owner, contractor and third party post insertion of inexcusable delays, compensable delays and excusable delays into the adjusted schedule to evince the delays aftermath from the owner, contractor or third party panoramas, correspondingly.

For delays scrutiny justification any party responsible delays are inflicted on the altered as-built schedule. The altered asbuilt schedule is compared with an as-built schedule, the time gap between project accomplishment day on the altered asbuilt schedule and the day behind placing delays is the party accountability. The approach to deduce number, essence of concurrency, net impact of concurrent delays along the critical path is described as follows.

From the as-built schedule the day on which concurrent delay occurred and its nature of concurrency is identified. Assuming concurrent delays as a virtual party, the modified ICBF method inserts number of concurrent delays occurring on the parallel critical activity into the adjusted schedule. The insertion work can be made either on first/last activity, or on an intermediate activity on which the start time of last activity depends, depending on analysis period involves which activity type. This will manifest the influence of time overshoot from the virtual party (concurrent delays) viewpoint. The altered asbuilt schedule is juxtaposed with the pre-schedule and the time lag betwixt the among-mentioned is observed. If time lag prevails, the altered ICBF technique distributes accountability to a virtual party by condensing virtual party's delay values from each study phase. The table 5.1 highlights an essence of concurrency which is contemplated to deduce the net outcome of concurrency. The impact of delayed days on direct cost and indirect cost of an activity is manipulated considering activities in each analysis period. To calculate cost of delayed days and working days direct cost per day as well as indirect cost per day of each activity must be known. The procedure is described in figure 5.1

Table 4.1 Concurrent delay outline and upshots

\begin{tabular}{|c|c|c|}
\hline $\begin{array}{c}\text { Party } \\
\text { accountable for } \\
\text { delay }\end{array}$ & $\begin{array}{c}\text { Synchronous with } \\
\text { delay responsibility of }\end{array}$ & Upshot \\
\hline Owner & Owner & $\begin{array}{c}\text { Remunerative to contractor, } \\
\text { blameworthy to owner }\end{array}$ \\
\hline Contractor & Contractor & $\begin{array}{c}\text { Blameworthy to contractor, } \\
\text { remunerative to owner }\end{array}$ \\
\hline Third party & Third party & $\begin{array}{c}\text { Justifiable but not } \\
\text { remunerative to either litigant }\end{array}$ \\
\hline
\end{tabular}

\begin{tabular}{|c|c|c|}
\hline Owner & Contractor & $\begin{array}{c}\text { Justifiable but not } \\
\text { remunerative to either litigant }\end{array}$ \\
\hline Owner & Third party & $\begin{array}{c}\text { Justifiable but not } \\
\text { remunerative to either litigant }\end{array}$ \\
\hline Contractor & Third party & $\begin{array}{c}\text { Justifiable but not } \\
\text { remunerative to either } \\
\text { litigant }\end{array}$ \\
\hline
\end{tabular}

Equations 1, 2 and 3 Yang and Yin et al.(2009) ascertains the forecasted project accomplishment span with project fulfilment span originated by the owner and contractor, respectively. Equations 4 and 5 establishes project fulfilment span caused by the third party and virtual party (concurrent delays). Delay accountability for the owner, contractor, third party and concurrent delay as virtual party are computed using equations $6,7,8$ and 9 respectively. After ascertaining the delay accountability in each scrutiny context, the approach encapsulates project delay accountability for each litigant from all scrutinized periods using equations10, 11 Yang and Yin et al. (2009), 12 and 13. Figure 1 pinpoints an analytical process. An equation 14 and 15 ascertains the Direct Cost and Indirect Cost linked with an activity focusing working days only. Equations16, 18 and 20 establishes the Direct Cost of an activity in no working day due to actions/inactions of contractor, owner and third party, respectively. Likewise an equation 17, 19 and 21 establishes the Indirect Cost linked with an activity in no working day. Equation 22 and 23 encapsulates the total Direct Cost and Indirect Cost of an activity. For each scenario, equations 24 and 25 find the total Direct Cost as well as the Indirect Cost. Finally, equation 26 determines the total cost in a current scrutiny period. Equations 27, 28, 29 and 30 will be employed to ascertain Planned Value, Earned Value, Cost Performance Index and Schedule Performance Index, respectively.

Delay scrutiny mechanism

The mechanism contemplates the initial and conclude (stretch) of critical activities A, C, F and I on the critical path A-C-F-I in the altered schedule. Four analysis periods are examined which are as follows.

\section{Scrutiny period 1 (day 30 to day 41)}

In this stretch, Type 1 activities (A to G) sustain their planned start and finish days. Activity $\mathrm{H}$ is considered as type 2 and so, is initiated on day 25 . Activities I and $\mathbf{J}$ are type 3 . So, activity I is programmed on its actual start day (30) with its as-planned duration of 5 days which shows that I must be completed on day 34 . Activity $\mathbf{J}$ starts on day 35 and maintains as-planned duration of 3 days (all delays are removed) and completed on day 37. So, day 37 is farthest point for further comparisons.

Firstly, delays caused by owner are assigned on the delayed activities. The stretch of activities- $\mathrm{H}, \mathrm{I}$ and $\mathrm{J}$ are 10days (1 day $\mathrm{C}$ delay), 5 days ( 2 days $\mathrm{C}$ delay), 3 days (0 day delay) respectively after scrutiny. The beginning times are day 25 , day 30 and day 35 for activity $\mathrm{H}$, I and $\mathbf{J}$ respectively which signifies that the project is completed on day 37 indicating that owner deserved no delay $(37-37=0)$.Next, contractor caused delay is assigned on the delayed activity. The stretch of 


\section{International Journal of Engineering Applied Sciences and Technology, 2019 \\ Vol. 4, Issue 3, ISSN No. 2455-2143, Pages 470-491 \\ Published Online July 2019 in IJEAST (http://www.ijeast.com)}

activities $\mathrm{H}, \mathrm{I}$ and $\mathrm{J}$ after analysis are 10days (0 day delay), 5 days (3 days NE delay), 3 days (0 day delay) respectively. These activities start on day 25, day 30 and day 35 respectively. These modifications reveal that the project is completed on day 37. So, contractor deserved no delay (37$37=0)$.

The proposed modified ICBF scrutiny assigns the force majeure delays on an activity. The stretch of activities $\mathrm{H}$, I and $\mathrm{J}$ after analysis are 10days ( 1 day FM delay), 5 days (2 days FM delay), 3 days (2 days FM delay) respectively. These activities start on day 25 , day 30 and day 35 respectively indicating that the project is completed on day 40. So third party deserved 3 days of delay $(40-37=3)$. The similar scrutiny assigns the virtual delays (concurrent delays) on the delayed activity. Two concurrent delays exist between critical activities $\mathrm{I}$ and $\mathrm{J}$. the proposed method assigns concurrent delays on the last activity (J). The stretch of activities $\mathrm{H}$, I and $\mathrm{J}$ after analysis are 10days, 5 days, 3 days (2 days concurrent delay) respectively. These activities start on day 25 , day 30 and day 35 respectively. Now, the project is completed on day 39 which indicates that virtual party deserved 2 days of delay (39-37=2).

\section{Analysis Period 2 (day 24 to day 29)}

Activities, A, B, C, D and G are categorized into type 1 and have their actual start and finish days; activity $\mathrm{E}$ is of type 2, begins on its actual start day, modified stretch is 13 days (actual duration (15 days) less a 2-day delay during the period) and completed on day 25; activity $\mathrm{F}$ is of type 3 , starts on its actual start day, modified stretch is 4 days and completed on day 27. Activity $\mathrm{H}$ is type 4, starts on its actual start day, modified stretch is 9 days (adjusted duration in previous period less 1 day delay) and completed on day 33. Activities I and $\mathbf{J}$ are categorized into type 5 , starts on day 28 ( F finishes on day 27), day 34 ( $\mathrm{H}$ finishes on day 33), maintains its planned duration of 5 days, 3 days respectively. These manipulations find day 36 is the baseline for project completion.

In this case, contractor deserved no delay because contractor caused no delay during this analysis period $(36-36=0)$. When the 2-day force majeure delay is imposed on activity $\mathrm{E}$, the modified project completion is day 36 , hence third party deserved no delay (36-36=0). If owner liability is considered (2-C delay on activity F, 1-C delay on activity $\mathrm{H}$ ), project completion day is 37 which highlights that owner deserved 1 day delay $(37-36=1)$. No concurrent delay is observed during this analysis period.

\section{Analysis period 3 (day 12 to day 23)}

Activity $\mathrm{A}$ is type-1, activities $\mathrm{C}$ and $\mathrm{G}$ are type-3, activity $\mathrm{E}$ is type- 4 and activities F, H, I and J are type-5. Similar to the process used in the previous two analysis periods, the baseline schedule of this analysis period is found to be day 30 and different party liability is found out. The results are such that owner deserved 3 days delay $(33-30=3)$, contractor deserved 1 day delay $(31-30=1)$, third party deserved 3 days delay (33$30=3$ ). In this case, 3 concurrent delays are observed on critical activities $\mathrm{C}$ and $\mathrm{E}$. Activity $\mathrm{E}$ governs the start time of last activity $\mathrm{J}$, under the rules for determining concurrent delays, the proposed method inserts 3 concurrent days delay on activity $E$ and the manipulations determine the project completion day is 33 which shows that virtual party (concurrent delays) deserved 3 days delay $(33-30=3)$.

\section{Analysis period 4 (day1 to day 11)}

Activities A and B are studied during this period. Finally, the scrutinized schedule acquired by the modified ICBF analysis is identical to the as-planned schedule, in which the project concludes on day 23. In considering owner liability, owner responsible time overrun are inflicted on the as-planned schedule which signifies that owner deserves 1-day delay. 3days non excusable delay for an activity A and 2-days non excusable delay for an activity $B$ are inflicted on the asplanned schedule which indicates that contractor deserves 3 days delay (26-23=3). 1-FM delay on activity A and 2-FM delay on activity $\mathrm{B}$ are imposed on the as-planned schedule which indicates that third party deserved 2 days delay (25$23=2$ ). Two concurrent delays are imposed on activity A which indicates project completion date is day 25. So, virtual party deserved (concurrent delay) 2 days delay $(25-23=2$ ).

\section{Results}

Omitting 8 days of lag caused by third party, time overrun caused by owner and contractor are 10 days $(18-8=10)$. The modified ICBF analysis resulted that there are 4-days contractor responsible overrun [the owner has answerability of 6 days overrun (10-4=6)], and the owner responsibility is of 5 days overrun [the contractor has answerability of 5 days overrun $(10-5=5)]$. The aggregate of overrun answerabilities by the contractor ( 5 days) and the owner ( 6 days) is 11 days. Therefore, the concurrent delay (1 day) can be studied by using the aggregate value (11 days) less overrun days answerable by owner and contractor (10 days). On day 4, non excusable delay concurrent with compensable delay is remarked. The net upshot is stated to such concurrent delay which consider it as excusable but not compensable to either party. Now, omitting 4 days of contractor answerable overrun, delay in days caused by owner and 3 party are $14(18-4=14)$. The scrutiny deduces that the owner causes 5-days overrun [the 3 party has answerability of 9 days overrun (14-5=9)], and the 3 party causes 8 days overrun [the owner has answerability of 6 days overrun $(14-8=6)]$. The aggregate of overrun responsibilities caused by the 3 party ( 9 days) and the owner (6 days) is 15 days. Therefore, the concurrent delay (1 day) can be studied by considering the aggregate value (15 days) less overrun days answerable by owner and 3 party (14 days). On day 21, force-majeure delay concurrent with compensable delay is remarked. The net upshot is stated to such concurrent delay which contemplates it as excusable but not compensable to either party. Similarly, ignoring 5 days of overrun caused by owner, delay in days caused by 3 party and contractor are $13(18-5=13)$. There are 4-days contractor responsible overrun [the 3 party has answerability of 9 days overrun (13-4=9)], and 


\section{International Journal of Engineering Applied Sciences and Technology, 2019 \\ Vol. 4, Issue 3, ISSN No. 2455-2143, Pages 470-491 \\ Published Online July 2019 in IJEAST (http://www.ijeast.com)}

the 3 party causes 8 days overrun [the contractor has answerability of 5 days overrun $(13-8=5)]$.

The aggregate of delay answerabilities by the contractor ( 5 days) and the 3 rd party (9 days) is 14 days. Therefore, the concurrent delay (1 day) can be studied by using the aggregate value (14 days) less overrun days caused by 3 party and contractor (13 days). On day 10, non excusable delay concurrent with 3rd party delay is observed. Using table such concurrent delay is excusable but not compensable to either party. The total concurrent delays along the critical path are 7 . Out of such 7 delays, three are observed. The other concurrent delay $(7-3=4)$ may be concurrent with single party such as compensable delay concurrent with compensable delay. From delay loaded as-built schedule, using equations 14 to26, results (in $\square$ ) are listed in table 5.3 and 5.4. The summation of total cost from all the scenarios ( $\square$ 18116666) defines the total cost of a project incurred in 41 days.

\section{Table 4.4 Total cost calculation}

\begin{tabular}{|c|c|c|c|}
\hline Activity & $\mathrm{DC}^{\mathrm{TOTAL}}{ }_{\mathrm{ACT}}$ & $\mathrm{IC}^{\mathrm{TOTAL}}{ }_{\mathrm{ACT}}$ & $\mathrm{TC}$ \\
\hline \multicolumn{4}{|l|}{ Scenario 4} \\
\hline A & 770000 & 1100000 & 1870000 \\
\hline B & 700000 & 1100000 & 1800000 \\
\hline $\mathrm{D}$ & 140000 & 220000 & 360000 \\
\hline Total & 1610000 & 2420000 & 4030000 \\
\hline \multicolumn{4}{|l|}{ Scenario 3} \\
\hline B & 70000 & 110000 & 180000 \\
\hline $\mathrm{C}$ & 720000 & 1320000 & 2040000 \\
\hline $\mathrm{D}$ & 490000 & 700000 & 1190000 \\
\hline $\mathrm{E}$ & 900000 & 1500000 & 2400000 \\
\hline G & 1500000 & 550000 & 2050000 \\
\hline Total & 3680000 & 4180000 & 7860000 \\
\hline \multicolumn{4}{|l|}{ Scenario 2} \\
\hline $\mathrm{E}$ & 240000 & 400000 & 640000 \\
\hline $\mathrm{F}$ & 360000 & 660000 & 1020000 \\
\hline $\mathrm{H}$ & 666666.7 & 450000 & 1116667 \\
\hline Total & 1266667 & 1510000 & 2776667 \\
\hline \multicolumn{4}{|l|}{ Scenario 1} \\
\hline $\mathrm{H}$ & 800000 & 540000 & 1340000 \\
\hline I & 720000 & 840000 & 1560000 \\
\hline $\mathrm{J}$ & 300000 & 250000 & 550000 \\
\hline Total & 1820000 & 1630000 & 3450000 \\
\hline
\end{tabular}

Implementation of Earned Value Management in delay analysis

Project takes 23 days to complete $(4.35 \%$ of work to be completed per day). Per unit of work per day in percent represents ratio of percent completion of work per day and total units of work per day. Total Cost per day for all activities is described in table. It is assumed that for no working day (wholly or partially), per day total cost is wasted. At the end of day 10 , only $23.18 \%$ of total work has been completed. The planned completion should have been $43.5 \%$. The Budget at Completion (BAC) is $\square 1,06,70,000$ and Actual Cost is $\square$ 1730000. Planned Value $(\square 46,41,450)$ is planned completion of work in percent multiplied by BAC and Earned Value $(\square 24,73,306)$ is actual completion of work in percent multiplied by BAC. Planned Value ( 0 delay) considers only units of work in computation while Earned Value shows the effect of delays on work progress. Therefore, the Earned Value is less than Planned Value. The Cost Performance Index (CPI) is the ratio of Earned Value to Actual Cost and is 1.42. This means that for every $\square 1$ spent, the project is producing only 142 cents in work.

The Schedule Performance Index (SPI) is the ratio of Earned Value to Planned Value and is 0.53 , shows that for every estimated hour of work, the project team is completing only 0.53 hour (approximately 31.8 minutes). The interpretation drawn is that project is under budget and behind the schedule. Risk management needs to kick-in. This case is in major trouble and corrective action needs to be taken. Both the contract parties should minimize the probability of delay occurrence in remaining activities so as to align project on schedule.

\section{Conclusion}

We can apply Earned Value Management to highlight impacts of no working day on overall cost performance and schedule performance of project and to overcome delayed time in remaining work by increasing resources application. The difference between planned value and actual value signifies barrier (in form of delay) in regular as-planned work and determination of Actual Cost of Work Performed reflects the barrier side effects on approved budgeted cost. The number of delays prevalent in project is directly proportional to the cost of project. The real state sector is stagnant, not very well developed in Lucknow region and time overrun due to disputes between clients. To reduce the chances of delays, cost management plan and inventory management register must be well prepared before execution phase. Effective quantity surveying measurements and systematic periodic cash flows enhance efficiency of real estate projects against over budget and time overrun.

\section{Notation}

The following notations are provided in the study:

$\operatorname{Dur}_{\mathrm{P}}{ }^{\text {act }}=$ actual time span in the p period;

$\operatorname{Dur}_{\mathrm{P}}{ }^{\text {base }}=$ expected project accomplishment time span in the $\mathrm{p}$ period;

Duty $^{\text {con }}=$ time overrun answerability to contractor;

Duty $^{\text {own }}=$ time overrun answerability to owner;

Duty $^{\text {con }}=$ time overrun answerability to contractor;

Duty $^{3 \mathrm{P}}=$ time overrun answerability to third party;

Duty $^{\mathrm{VP}}=$ time overrun answerability to virtual party (concurrent delays);

$\operatorname{Dur}_{\mathrm{P}}{ }^{\text {own }}=$ altered completion days taking owner's duty in the $\mathrm{p}$ period;

$\operatorname{Dur}_{\mathrm{P}}{ }^{\text {con }}=$ altered completion days taking contractor's duty in the $\mathrm{p}$ period;

$\operatorname{Dur}_{\mathrm{P}}{ }^{3 \mathrm{P}}=$ altered completion days taking third party's duty in the $\mathrm{p}$ period; 


\section{International Journal of Engineering Applied Sciences and Technology, 2019 \\ Vol. 4, Issue 3, ISSN No. 2455-2143, Pages 470-491 \\ Published Online July 2019 in IJEAST (http://www.ijeast.com)}

$\operatorname{Dur}_{\mathrm{P}}{ }^{\mathrm{VP}}=$ altered completion days taking virtual party's (concurrent delay) duty in the p period;

$\operatorname{Dur}_{\mathrm{p}}{ }^{\mathrm{C}}=$ Effected time span by compensable delays in the $\mathrm{p}$ period;

$\operatorname{Dur}_{\mathrm{p}}{ }^{\mathrm{FM}}=$ Effected time span by force-majeure delays in the $\mathrm{p}$ period;

Dur $_{\mathrm{p}}{ }^{\mathrm{NE}}=$ Effected time span by non-excusable delays in the $\mathrm{p}$ period;

Dur $_{\mathrm{p}}{ }^{\text {cnert }}=$ Effected time span by concurrent delays in the $\mathrm{p}$ period;

$\mathrm{DC}_{\mathrm{act}}{ }^{\mathrm{WD}}=$ direct cost of an activity in working days;

$\mathrm{IC}_{\mathrm{act}}{ }^{\mathrm{WD}}=$ indirect cost of an activity in working days;

$\mathrm{DC}_{\mathrm{act}}{ }^{\mathrm{NE}}=$ direct cost of an activity for delayed days caused by contractor;

$\mathrm{DC}_{\mathrm{act}}{ }^{\mathrm{C}}=$ direct cost of an activity for delayed days caused by owner;

$\mathrm{DC}_{\mathrm{act}}{ }^{3 \mathrm{P}}=$ direct cost of an activity for delayed days caused by third party;

$\mathrm{IC}_{\mathrm{act}}{ }^{\mathrm{NE}}=$ indirect cost of an activity for delayed days caused by contractor;

$\mathrm{IC}_{\mathrm{act}}{ }^{\mathrm{C}}=$ indirect cost of an activity for delayed days caused by owner;

$\mathrm{IC}_{\mathrm{act}}{ }^{3 \mathrm{P}}=$ indirect cost of an activity for delayed days caused by third party;

$\mathrm{DC}_{\mathrm{act}}{ }_{\text {total }}^{=}=$total direct cost of an activity;

$\mathrm{IC}_{\text {act }}^{\text {total }}=$ total indirect cost of an activity;

$\mathrm{DC}_{\mathrm{i}}^{\text {total }}=$ direct cost in an analysis period;

$\mathrm{IC}_{\mathrm{i}}^{\text {total }}=$ indirect cost in an analysis period;

$\mathrm{TC}_{\mathrm{i}}^{\text {total }}=$ total cost in an analysis period;

Dur $_{\text {act }}{ }^{\mathrm{WD}}=$ working days of an activity;

Dur $_{\text {act }}{ }^{\mathrm{C}}=$ delayed days caused by owner;

Dur $_{\text {act }}{ }^{\mathrm{NE}}=$ delayed days caused by contractor;

Dur $_{\text {act }}{ }^{\mathrm{FM}}=$ delayed days caused by third party;

$\mathrm{PV}=$ planned value of the work to be completed in a given time;

$\mathrm{EV}=$ earned value of the work actually completed to date;

$\mathrm{AC}=$ Actual Cost is the total cost incurred for the actual work completed to date;

$\mathrm{BAC}=$ Budget at Completion is the total planned value for the project;

CPI = Cost Performance Index;

SPI = Schedule Performance Index;

\section{POST APPLICATION OF LEAN PRINCIPLES FOR DELAY RESOLUTIONS TIME IMPACT STUDY OF REAL ESTATE SECTOR CONSTRUCTION PROJECTS}

One of the long standing issues in the field of real estate sector construction disputes claims is the determination of a party responsible for occurrence of delays, delayed duration and its impact on as- planned construction schedule. A classification of delay analysis models shows that no model yet exists that is able to collect the causes of construction delays with determination of party responsible for it by evaluating time overrun due to addition of various delays in as-planned construction schedule, and to suggest delay prevention measures to minimise their arrival in real estate projects. The purpose of this document is to develop and test of such a design method to find construction delays liability in real estate sector construction projects by collecting delays arrival causes with the prevention measures that should be adopted to minimize occurrence of construction delays. A methodology is developed for resolving real estate construction disputes claims by finding a party responsible for delay arrival and enable one to follow lean construction principles to avoid same type of delay in other work packages and in other real estate construction projects. The tests of this design method with the participants reveal that by completing the steps in the proposed design procedure, users will have detail of causes of time overrun of an activity/work package of real estate construction projects, the responsible delay caused party will be asked for compensation based on delayed time and the last step of design method provides suitable principles to users to be efficient in performing delay- free work.

\section{Introduction}

Delay could be defined as the time overrun either beyond the contract date or beyond the date that the parties agreed upon for delivery of a project Assaf and Al-Hejji et al. (2006). Delays can lead to many stereotypes i.e. disputes between owners and contractors leading to arbitration, increased costs, loss of productivity and revenue, and contract termination. In India, a study conducted by the Infrastructure and Project Monitoring Division of the Ministry of Statistics and Program Implementation in 2004 reported that out of 546 central sector projects costing about $\$ 45$ trillion, approximately $40 \%$ are behind schedule, with delays ranging from 1 to 252 months Iyer and Jha et al. (2006). Researchers and practitioners have used many techniques to assess project delays and apportion delay responsibility among the parties involved. There are various methods that exist for schedule delay analysis.

No one method is currently acceptable for all projects participants or suitable for all situations. According to Ahsan and Guha et al. (2010), Indian construction projects were worst on account of project completion and delivery as compared to that in China, Hong Kong, Thailand, and Bangladesh, the average schedule over-run is near about $55 \%$ in Indian scenario.

\section{An introduction to delay analysis standards method}

Delay analysis is the procedure of comparing as-planned and other adjusted schedules by evaluating the magnitude, impact and significance of the variation between the baseline and operating schedules along with quantifying the effect of delays impacts on a project schedule. The time impact analysis procedure was recommended for use. Time impact analysis is the process of quantifying and apportioning the effect of delay or change on a project schedule. The time impact method of delay analysis, also referred to as TIA, is a technique similar to the impacted as-planned analysis, which forecasts or predicts a delay's effect on a project's completion date and involves the insertion or addition of activities indicating 
delays or changes into an updated schedule representing progress up to the point when a delay event occurred to determine the impact of those delay activities.

\section{Delay cause approach}

The delay-cause approach is based on the identification of delay as independent of the planned duration for an activity, and is driven by the nature of the events. This approach aligns the delay causes based on the available documentations and to understand the causes of delay.

\section{Time impact analysis definition and uses}

Time Impact Analysis (TIA) is a scheduling technique used to quantify the effects of an unplanned event, quantify the effects of increases the work scope, evaluate potential impacts to the schedule for acceleration or delay (A TIA is forward-looking). The TIA is identified in numerous industry publications concerning the subject of delay analysis methodologies and is the best methodology for determining the extent of impact from a potential delay event. The schedule must have a valid critical path and it is applied to the most recently updated and accepted critical path method (CPM) schedule. When done in a prospective, or forward looking, manner, a TIA can promote negotiation and ultimate settlement of any ramifications of a delay event.

From CPM in Construction Management, $6^{\text {th }}$ edition book by James O'Brien and Fred Plotnick, Time impact evaluationUse of a fragnet or sub network to evaluate the impact of an event such as a change of order or unusual occurrence on the baseline schedule; known as TIE. This is also known as time impact analysis.

AACE International recommended practice no. 52R-06, The TIA is a 'forward looking, 'prospective schedule analysis technique that adds a modelled delay to an accepted contract schedule to determine the possible impact of that delay to project completion.

The TIA is determined by adding impacts to schedules which are statuses at the end of specific windows or impact periods, typically the monthly schedule updates prepared during the project. If the entire period of the project is considered as one as-planned schedule, the TIA can also be performed in windows or periods of time, where the statuses schedule and its then current critical path can be analyzed separately for each window or period, and cumulatively for the project. The goal of the systematic time impact analysis approach is to give full consideration to the actual effect of events individually and acting together, and to evaluate the effect of ongoing delays.

The goal of the method is to examine the evolution of the critical path and the impact of delaying events on that path (Bramble et al. 1990). The time impact analysis approach is often the most time-consuming delay analysis method; however, it can be very accurate, has the potential to be the least controversial and most analytical, and can be equitable to all parties (Stumpf 2000).

Lean implementation in Lucknow (U.P, India)

In recent years, the state-owned and private companies have gradually started to accept the lean approach. So far, most companies have only focused on the application of lean tools and very few have fully started the whole lean enterprise transformation. Lucknow firms held three different attitudes towards lean principles. Firstly, many companies claimed that they are lean companies because they have already implemented 5-S activities, or etc., but they have failed to appreciate the interrelationships between many other tools. Secondly, many companies believed that occurrence of delays are due to an act of God and lean principles will not stop delay occurrence. Lastly, some companies thought that they completed their lean transformation years ago. Figure 2 highlights the forces behind the potential for implementing lean principles in the Lucknow (U.P, India).

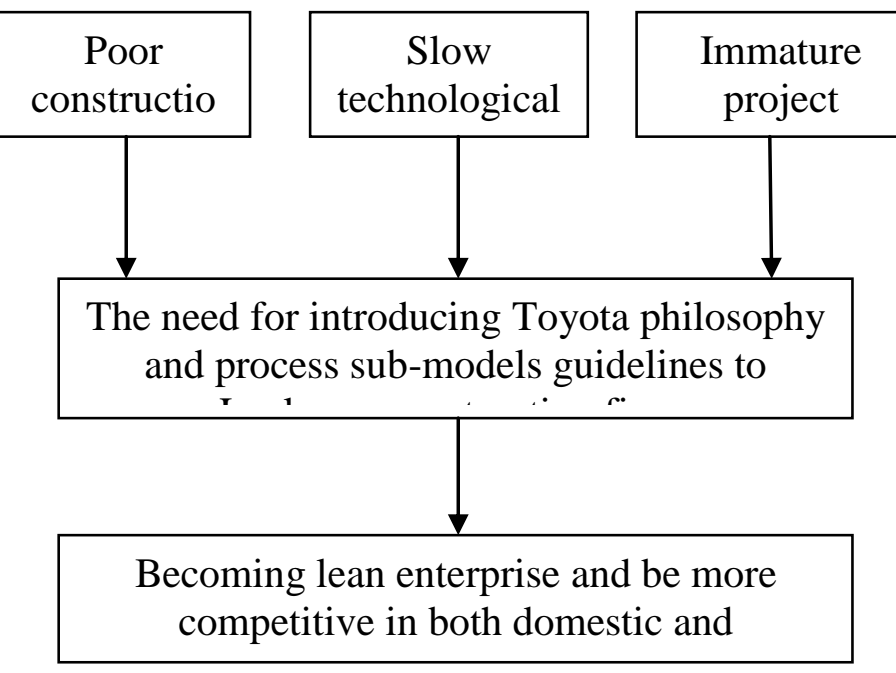

Figure 5.1 Driving forces behind the need for introducing lean principles in Lucknow construction firms

Case study

The example, which will be used, is comprised of four activities and three delays that occur on the short project. The four activities are (1) the excavation of soil, (2) owner approval of .road drainage structure drawings, (3) installation of a new road drainage structure, and finishing with (4) soil backfill. The as-planned schedule and as-built schedule with delay information for case are represented in table 6.1 and 6.2 respectively.

Table 5.1 as-Planned and As-Built Schedule

\begin{tabular}{|c|c|c|c|c|c|}
\hline Activity & Duration & \multicolumn{2}{|c|}{ As-planned } & \multicolumn{2}{|c|}{ As-built } \\
\hline & & Start & Finish & Start & Finish \\
\hline $\begin{array}{c}\text { Owner } \\
\text { approved } \\
\text { drawings }\end{array}$ & 1 & 1 & 1 & 1 & 1 \\
\hline Excavate soil & 4 & 1 & 4 & 1 & 4 \\
\hline $\begin{array}{c}\text { Install } \\
\text { drainage }\end{array}$ & 6 & 3 & 3 & 11 & 16 \\
\hline
\end{tabular}




\begin{tabular}{|c|c|c|c|c|c|}
\hline structure & & & & & \\
\hline Backfill & 2 & 9 & 10 & 17 & 18 \\
\hline $\begin{array}{c}\text { Owner } \\
\text { related delay } \\
\text { Drawing } \\
\text { approval }\end{array}$ & 5 & - & - & 2 & 6 \\
\hline $\begin{array}{c}\text { Contractor } \\
\text { related delay } \\
\text { Equipment } \\
\text { unavailability }\end{array}$ & 4 & - & - & 3 & 6 \\
\hline $\begin{array}{c}\text { Excusable } \\
\text { delay } \\
\text { Rain delay }\end{array}$ & 5 & - & - & 6 & 10 \\
\hline
\end{tabular}

Table 5.2 Road drainage structure example delay information

\begin{tabular}{|l|l|}
\hline $\begin{array}{l}\text { Owner } \\
\text { responsible } \\
\text { delay }\end{array}$ & $\begin{array}{l}\text { The owner fails to approve road drainage } \\
\text { structure drawings in time during } \\
\text { excavation work and ready the drawings } \\
\text { 5days late. }\end{array}$ \\
\hline $\begin{array}{l}\text { Contractor } \\
\text { responsible } \\
\text { delay }\end{array}$ & $\begin{array}{l}\text { The contractor does not have the proper } \\
\text { equipment on site required to install the } \\
\text { drainage structure on time. An extra 4 days } \\
\text { are needed to get equipment. }\end{array}$ \\
\hline $\begin{array}{l}\text { Excusable } \\
\text { delay }\end{array}$ & $\begin{array}{l}\text { Severe rainfall begins during construction } \\
\text { phase. The result is a 5 day rain delay }\end{array}$ \\
\hline
\end{tabular}

\section{Conclusion}

In the discussion of the "process" part of the Toyota way model, an Endeavour has been made to link a number of Toyota way principles to the as-built schedule as a necessary change for better implementation cum output. It should be noted that the commitment of management, as well as their awareness and understanding, is the most important prerequisite, without which it is not possible to successfully implement this methodology in practice. Performing a detailed time impact analysis on real estate sector construction projects, which are often highly impacted and disrupted, can be challenging. An assessment on the limitations on available project data and information that would support a detailed time impact analysis should be given a high priority before starting a time impact analysis. It is important to note that Toyota way philosophy and process sub-model is more than a set of methods for eliminating waste. In contrast, it can be viewed as a socio-technical system that recognizes the importance of people and the lean construction principles and can aid in achieving total quality management in construction activities by train staff and managing employees to minimize occurrence of delays. Time impact method of delay analysis can be used in delay liability calculation and to solve delay related issues.

\section{APPLICATION OF LEAN PRINCIPLES TO DEVELOP PROSPECTIVE SOLUTIONS FOR MINIMISATION SCHEDULE DELAYS IN INDIAN REAL ESTATE SECTOR}

\section{Introduction}

The target of all Stakeholders included in construction projects - owners, contractors, engineers and consultants in either the public or private sector is to successfully discharge the project on schedule, within planned budget, with the highest quality and in the safest manner. Though, delay is a major constraint of construction industry globally especially in developing countries. It has been observed that most projects, mainly large \& complex ones, do not end successfully. Due to the inherent risks and increasing complexity of modern construction projects, delays have become common constraints in the industry. Mathematically, construction delays are the function of time. Delay could be defined as the time overrun either beyond the contract date or beyond the date that the parties agreed upon for delivery of a project. Delays can lead to many stereotypes i.e. disputes between owners and contractors leading to arbitration, increased costs, loss of productivity and revenue, and contract termination. Real estate construction projects have great deal of preoccupation with increasing safety and regulatory requirements, technological \& quality aspects, changing socioeconomic environment, scope modifications and increase in cost with passage of time due to inflation \& escalation, which have adverse effect on the project performance. The organizational objectives can be met through identifying these causes and efficient \& effective use of project management processes and techniques to manage and control the projects. The Toyota Way Model is employed to solve some of the time overshot limitation. It is necessary to know the determinants of Toyota Way Model in terms of their importance to minimize delaying situation.

\section{Literature review}

Delays happen in most construction projects, whether simple or complex. In construction, delay could be defined as the time overrun either beyond the contract date or beyond the date that the parties agreed upon for delivery of project, Assaf and Al-Hejji et al. (2006).

A project consists of a collection of activities. The delays activities can cause delays in the completion of the project. Delay analysis is used to determine the cause(s) of the delay and to know whether project needs extension or not. An extension of time relieves the contractor from the liability for damages Lowsley and Linnett et al. (2006). The analysis of delays in construction projects is difficult and complicated because of the large number of individual activities that have to be dealt with, even for a relatively simple project. A medium-sized project may consist of hundreds of activities, many of which may take place at different times and with different durations than originally planned Shi et al. (2001). Some activities may be delayed or accelerated, and such 


\section{International Journal of Engineering Applied Sciences and Technology, 2019 \\ Vol. 4, Issue 3, ISSN No. 2455-2143, Pages 470-491 \\ Published Online July 2019 in IJEAST (http://www.ijeast.com)}

changes may partially or fully, or may not, affect the project completion date.

In the study of Alaghbari et al. (2007), delay is generally acknowledged as the most common, costly, complex and risky problem encountered in construction projects. Majid et al.(2006) stated that delays can be minimized when their causes are identified. Identification of the factors that contributed to the causes of delays has been studied by numerous researchers in several countries. Delay is a situation when the contractor, consultant, and client jointly or severally contributed to the non-completion of the project within the original or the stipulated or agreed contract period. Because of the overriding importance of time for both the Owner (in terms of performance) and the Contractor (in terms of money), it is the source of frequent disputes and claims leading to lawsuits.

\section{Causes of delays}

Researchers have studied the many causes of delay in the construction industry. Lo et al. (2006) summarized some of the studies that took place from 1971 to 2000 (Table7.1).

Table6.1 Summary of previous studies of the causes of delays in construction projects

\begin{tabular}{|l|l|l|}
\hline Researcher & Country & Major causes of delay \\
\hline $\begin{array}{l}\text { Baldwin et. } \\
\text { al. (1971) }\end{array}$ & $\begin{array}{l}\text { United } \\
\text { States }\end{array}$ & $\begin{array}{l}\text { Inclement weather, shortages of } \\
\text { labor supply, subcontracting } \\
\text { system }\end{array}$ \\
\hline $\begin{array}{l}\text { Arditi et. al. } \\
(1985)\end{array}$ & Turkey & $\begin{array}{l}\text { Shortages of resources, delay in } \\
\text { design work, financial } \\
\text { difficulties faced by public } \\
\text { agencies and contractors, } \\
\text { organizational difficulties, } \\
\text { frequent changes in orders }\end{array}$ \\
\hline $\begin{array}{l}\text { Assaf et. al. } \\
(1995)\end{array}$ & $\begin{array}{l}\text { Saudi } \\
\text { Arabia } \\
\text { contractors, shortages of labor } \\
\text { supply, poor workmanship, } \\
\text { changes in orders }\end{array}$ \\
\hline $\begin{array}{l}\text { Okpala and } \\
\text { Aniekwu } \\
(1998)\end{array}$ & Nigeria & $\begin{array}{l}\text { Shortages of supply, failure to } \\
\text { pay for completed works, Poor } \\
\text { contract management }\end{array}$ \\
\hline $\begin{array}{l}\text { Dlakwa and } \\
\text { Culpin } \\
\text { (1990) }\end{array}$ & Nigeria & $\begin{array}{l}\text { Fluctuations in materials, plant } \\
\text { and labor costs, delays in } \\
\text { payments by agencies to } \\
\text { contractors }\end{array}$ \\
\hline $\begin{array}{l}\text { Semple et. } \\
\text { al.(1994) }\end{array}$ & Canada & $\begin{array}{l}\text { Increases in the scope of work, } \\
\text { inclement weather, restricted } \\
\text { access }\end{array}$ \\
\hline
\end{tabular}

\section{Methodology}

The methodology espoused is to negotiate the time influence delay scrutiny study of community based real estate projects through juxtaposing as-planned schedule and as-built adjusted schedule with delay statistics, 100 in gross, to decipher the various determinants influencing the timely conveyance of construction projects. 57 determinants are spotted within the scope of knowledge and codified into 7 brackets. The rate of occurrence of examined determinants is manifested in incidence based clustered column chart. The scrutiny denouements by pinpointing the extent to which the Toyota Way principles are adopted

It then analyses their importance for firms or projects from the perspectives of the respondents with expected benefits based on delay prevention factors for real estate construction industries in terms of the implementation of two different themes of the Toyota Way model post discussing the findings from both the survey and interviews from both the investor's and the contractor's viewpoint in the planning, contracting and construction of a project. It is important to reflect on what strategies should be taken to overcome the weaknesses diagnosed, especially regarding framework of neutralization rooted system to lessen delay event.

\section{Need for research}

Real estate construction industries within realm of Lucknow (India) are shaped by four precarious performance facets, namely, quality, productivity, profitability and project management. In order to accomplish serviceably all the performance facets, ethics of Toyota way model can favorable. In actual enactment, it seems that no single real estate construction firm has fully demonstrated its ability, capacity, or readiness to implement all the principles of Toyota Way model which manifests gaps between two. A requisite is to shoot Toyota management postulates to real estate construction firms for exertions need to be utilized as anti-delay remedy to ameliorate the approach within each different principle: the contribution of employees and workers (manpower), the contribution of materials and machines and the contribution of workplace design.

\section{Research design}

The survey research tactics has been espoused for this research. The target population consists of contractors, investors and technical staffs of real estate construction industries.

\section{Questionnaire outline}

A questionnaire survey is progressed after analyzing 100 work schedules to acquire the perspective and cognizance based on the relative importance index (in terms of importance) from the skilful respondents concerning to the construction delays circumvention suing Toyota way sub-principles in real estate construction industries and to ascertain expected consequences with the motive of narrowing the gap between the Indian real estate construction practices that currently prevail and the Toyota Way-styled practice for reducing delays.

\section{Respondent background}

The questionnaire was distributed among investors, contractors and project managers, 345 in gross, of real estate construction firms. Out of which, 280 responses were acquired consisting of 65,130 and 85 responses from engineers, 


\section{International Journal of Engineering Applied Sciences and Technology, 2019 \\ Vol. 4, Issue 3, ISSN No. 2455-2143, Pages 470-491 \\ Published Online July 2019 in IJEAST (http://www.ijeast.com)}

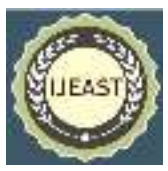

contractors and project managers respectively. All respondents had average working experience of ten years. Their responses were deployed for grouping awaited benefits in enacting Toyota Way postulates in real estate construction industries.

\section{Time impact analysis definition and uses}

The time impact analysis is identified in numerous industry publications concerning the subject of delay analysis methodologies for determining the extent of impact from a potential delay event. For gathering delay factor information using time impact method, it is required to have an as planned schedule to define a contractor's original plan for performing its entire scope of work, as-built schedule reflects the actual succession of the events that happened during execution of the project, entitlement schedules consisting of either extended asplanned schedules (i.e. the as-planned schedule with certain classes of delays added) or collapsed as-built schedules (i.e. the as-built schedule with certain classes of delays removed), and lastly adjusted schedule for quantification and identification of impact of schedule variances on the project also it is useful in determining the effects of different types of delays on the project completion date. It is prior to mention that these are legally acceptable and vital for settlement of disputes.

\section{Introduction to the Toyota way principles}

In recent years, the state-owned and private companies have gradually initiated to undertake the lean approach so as to lessen probability of cost and time overrun of construction projects. So far, most companies have only focused on the application of lean tools and very few have fully started the whole lean enterprise transformation. Lucknow firms held three different attitudes towards lean principles. Firstly, many companies claimed that they are lean companies because they have already implemented 5-S activities, or etc., but they have failed to appreciate the interrelationships between many other tools.

Secondly, many companies believed that occurrence of delays are due to an act of God and lean principles will not stop delay occurrence. Lastly, some companies thought that they completed their lean transformation years ago.

Learning from Toyota and its underlying principles is a novel undertaking in the real estate construction industry. Establishing an implementation framework of the Toyota Way principles for the Indian real estate construction firms is important as this management philosophy has the potential to help solve the problems which plaque the Real estate construction industries. Following are the main pinpoints.

"Based your management decision on the long-term philosophy, even at the expense of short-term financial goals". Sometimes either contractor or third party causes delays in construction projects to make more profit. But it must not the driving purpose of contractor or owner and must adopt strategy of "constancy of purpose" for growth in sales of deliverables and hence profit (sense of purpose).To avoid delays during construction work/designing phase construction organization must not dismiss its employees because of a temporary downturn and it must sustain a long-term relationship with the suppliers (long term perspectives).Construction industry must have unique spirit of "let's do it ourselves" and self reliance. Self reliance helps in developing core-competitiveness. At firm, the champion to self-reliance is responsibility for its own successes and failures (selfreliance and responsibility).

The management endeavors to ensure that all tram members and departments realize their dual roles, namely that they are not only the customers of the previous operation but also the suppliers to the next operation downstream. In order to avoid delays due to lack of communication, inadequate manual operation, loading and unloading parts from equipments construction resources like equipments, labors, machines must be arranged around the edge of a u-shape, allowing workers to walk the shortest distance from process to process and performing other manual operations .It will assist communication and allows the workers access to a number of machines and to be able to operate several machines. The project is not only delayed but the morale of workers plummet because of non-payment or irregular payment of wages. Subcontractors and suppliers of materials and components and their employees are likewise affected. The overburden of work on labors, staff and on equipments reduce their efficiency and further rate of performing work slows down due to sickness.

In this case situation of staff getting sick is common and so it will act as barrier to construction process. Standardized tasks are the foundation for keeping project work as per defined schedule and imply that all work should be highly specified in terms of timing, content, sequence and outcome. Creating standardized work requires identifying the repeatable elements of a process, assessing the best way to perform those elements, developing a reliable method to ensure the performance of those elements and then performing the reliable method according to a required time. Visual management in construction is needed due to a number of factors such as physical environment involved, construction technology and contractual relations that result in difficulties visualizing the flow of work in progress on-site. Basically, visual management practices can be classified into different layers of visual workplace framework namely visual order, visual standards, visual measures and controls and visual guarantees. Real estate sector organization, which is still very labour intensive, aims to be on the cutting edge of technology. Thoroughly test new technology, technology must support people and company values and technology must improve people. Building professionals have attempted various new technologies, in the hope of improving performance, in an industry which is known for its slow rate of adopting new technology.

\section{Data processing}

The as-planned schedules in association with as-built schedules of 100 real estate projects are mannered and juxtaposed to ascertain the aftermath of all-inclusive delays on 
as-planned conveyance of projects. Their durations are pinpointed in figure7.1. Additionally the differences between as-planned and as-built schedule of a project manifests time overrun. The scope of overrun is demonstrated in figure 7.2. The rate of occurrence of examined determinants is manifested in seven frequency based clustered column chart as shown in figures7.3 to 7.9 and the most critical delay causing factors are grouped in separate cases.

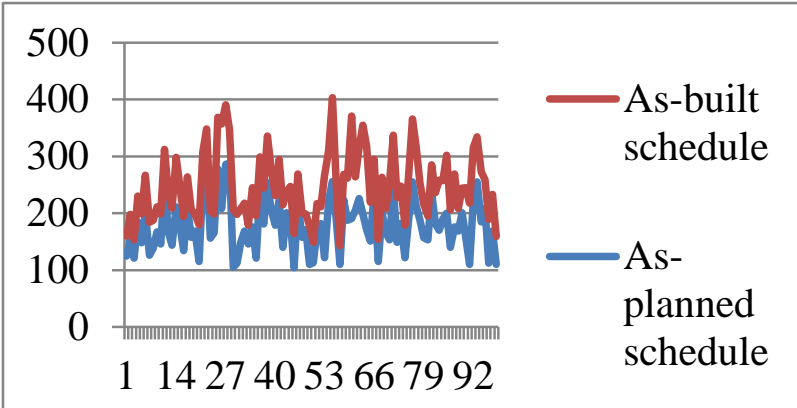

Figure 6.1 Range of as-planned schedules with as-built schedules

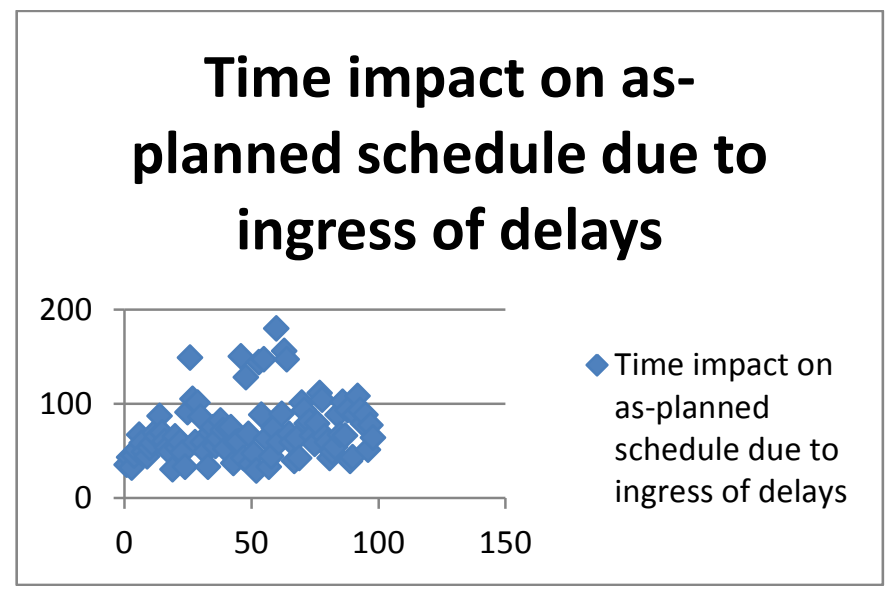

Figure 6.2 Time impact study

\section{Consultant related factors}

Lack of.

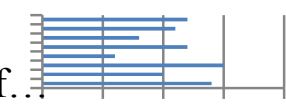

Consultant $\begin{array}{lllll}55 & 60 & 65 & 70 & 75\end{array}$
Figure 6.3 Frequency of consultant responsible delay factors

\section{Contractor related factors}

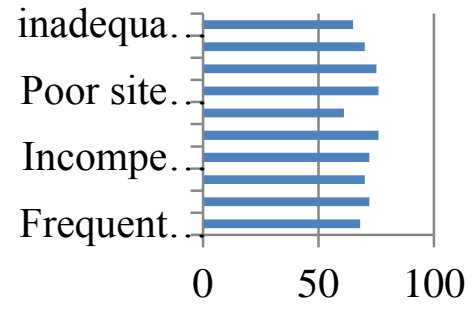

Contractor related factors

Figure 6.4 Frequency of contractor responsible delay factors

\section{Design related factors}

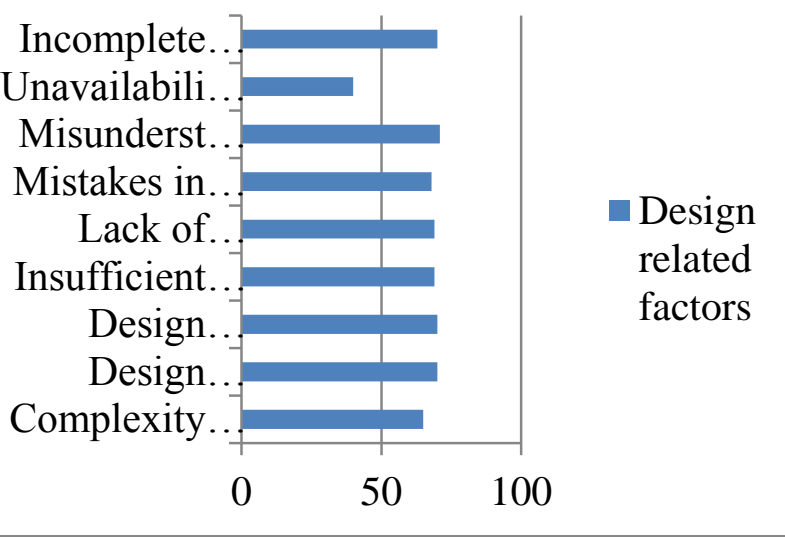

Figure 6.5 Frequency of design responsible delay factors

\section{Equipment related factors}

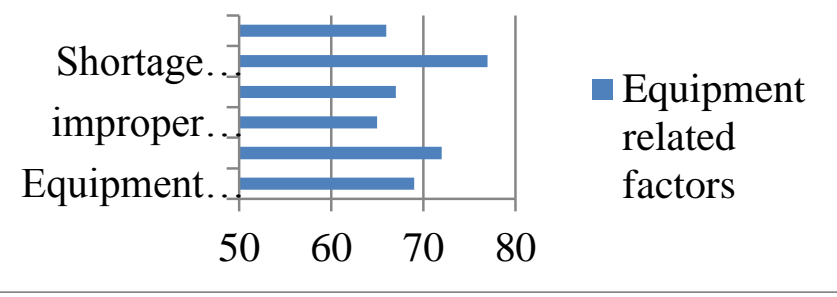

Figure 6.6 Frequency of equipment responsible delay factors 


\section{Labor related factors}

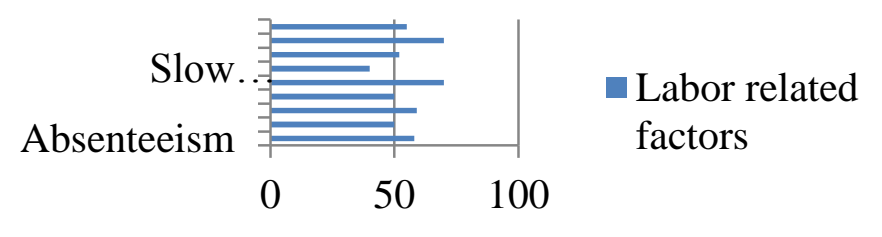

Figure 6.7 Frequency of labor responsible delay factors

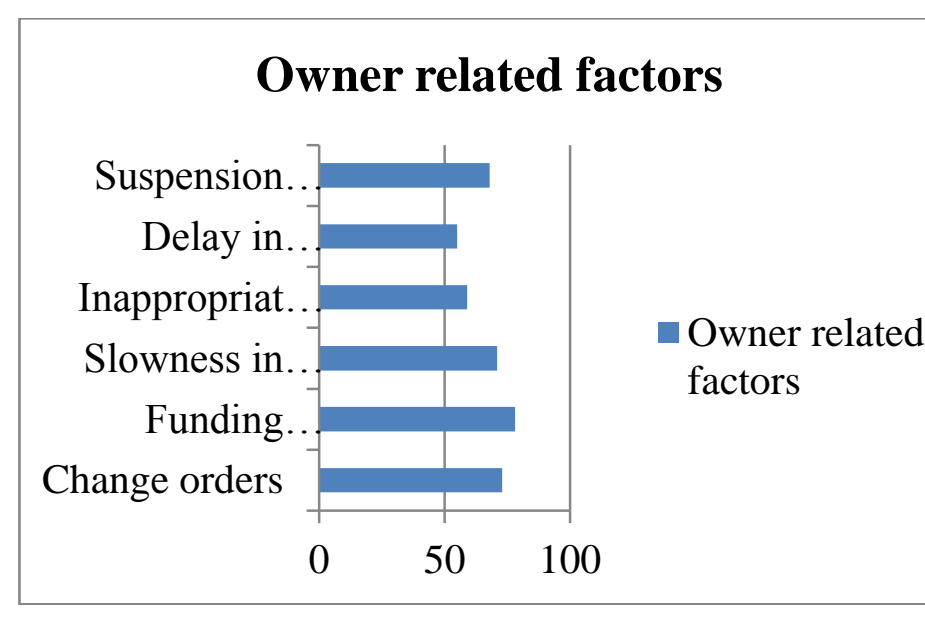

Figure 6.8 Frequency of owner responsible delay factors

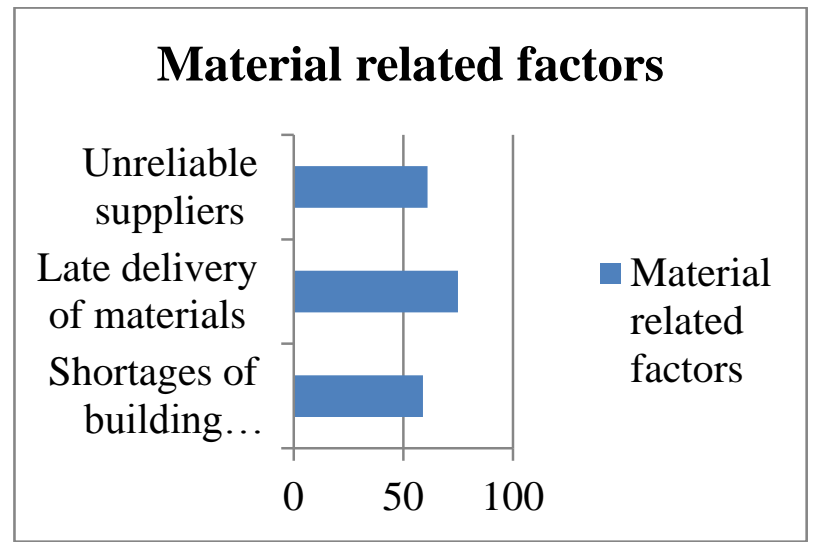

Figure 6.9 Frequency of material related delay factor

\section{CONCLUSION}

Implementing a comprehensive time impact analysis on real estate sector construction project which are often highly affected and disrupted can be challenging. An assessment on the constraints on accessible project data and information that would support a comprehensive time impact analysis should be given a high priority before initiating a time impact analysis.
The guidelines of Toyota way postulates are accomplished with the aim of narrowing the gap between the Indian practices that currently prevail and the Toyota Way-styled practice.

In doing so, it is anticipated to facilitate real estate construction firms to administer their organizations and construction projects more systematically and coherently from the beginning to the end. The framework implementation guidelines not only list the Toyota Way-styled practices and depict how these should be implemented in a holistic way, but these also offer strategies for implementing them effectively. This framework can also be used by the top management of the firm, especially as this is essential for effecting organizational culture changes, mindset changes, etc. All such changes require the commitment of top management who need to take the initiative to become champions for facilitating implementation. Overall, this frame- work can be used as a practical guideline covering a number of areas, including organizational philosophy, process, people and partners, and problem-solving.

\section{CONCLUSIONS AND RECOMMENDATIONS}

\section{CONCLUSIONS}

Based on the studies, the following conclusions were drawn: 1. The ninety nine delay factors were identified from the literature review for the study purpose.

2. The ninety nine delay factors grouped into nine major categories: contractor, consultant, owner, material, design, equipment, labor, external and project related delays.

3. Top most delay causing factor is found to be delay in obtaining permits from municipality which is grouped into external related factors.

4. Least delay responsible factor is sight from labours category i.e. Labour strikes due to revolutions.

5. The frequency of occurrence helped in finding out the delay factors frequently influencing the construction projects.

6. The degree of severity for each delay factor indicated the influence of particular delay factor in construction industries.

7. Based on RII, FI, SI and RI, the OI was calculated for each delay factor. The OI helped in finding out the ranks of delay factor.

8. The guidelines of Toyota way postulates are accomplished with the aim of narrowing the gap between the Indian practices that currently prevail and the Toyota Way-styled practice. In doing so, it is anticipated to facilitate real estate construction firms to administer their organizations and construction projects more systematically and coherently from the beginning to the end.

9. An assessment on the constraints on accessible project data and information that would support a comprehensive time impact analysis should be given a high priority before initiating a time impact analysis. 


\section{International Journal of Engineering Applied Sciences and Technology, 2019 Vol. 4, Issue 3, ISSN No. 2455-2143, Pages 470-491 \\ Published Online July 2019 in IJEAST (http://www.ijeast.com)}

\section{RECOMMENDATION}

\subsubsection{General Recommendations}

1. As there is a penalty applied to those contractors who fail to deliver projects on time, it is also important to maintain incentives for those who deliver projects ahead, within budget and with super quality.

2. As in the manufacturing industry an annual prize is given to the best factory, similar idea should be implemented in the construction industry.

3. The Indian construction industry lacks the research and development and the government should encourage and support such strategies.

4. It is recommended to establish of a governmental authority which concerns with developing the Indian construction industry and tackles the obstacles that are facing it.

5. It is important to reconsider the governmental strategies that encourage the selection of the lowest bidding contractors and to improve the routine procedures and requirements that are required for obtaining work permits.

6. Contractors should pay more attention in preparing effective planning and scheduling. During construction, planning and scheduling may be revised if necessary.

7. Site management and supervision should be done correctly. Administrative staff should be assigned to make necessary arrangements to complete projects within the specified time while meeting quality and cost requirements.

8. Owners may demand design changes during construction, but only to the extent that no adverse effects occur with respect to mission-critical activities.

9. Delivery of construction materials to a site should not be late so that work may be executed in the planned order.

10. Generally, large projects may entail having many subcontractors working under main contractors. If a subcontractor is capable and reliable, the project can be completed on time as Planned. If the subcontractor underperforms because of inadequate experience or capability, the project may face delays. The use of many subcontractors may lead to a high risk of delays.

11. Inspection and testing by consultants is an important activity during construction since poor quality inspection may result in lower quality of work.

12. The quality and experience of the labour force can have a major impact on projects. Unqualified workers may lead to inefficient work and cause accidents during construction.

13. A change order is work added to or deleted from the original scope of work of a contract, which may alter the original contract amount or completion date.

Change orders often lead to claims and disruption of work due to inadequate analysis of the project in its initial stages. Also, contract conditions corresponding to change orders should be carefully understood.

14. Delays in deliveries to construction sites, approval of design documents, and progress payments are delay factors caused by owners. Sites should receive deliveries as soon as possible after a project is awarded. Design documents should be approved promptly; otherwise, work progress could be delayed. Progress payments should be made on time to contractors to finance the work.

15. Owners should make decisions as quickly as possible so as not to prevent projects from being completed on time.

16. Since many parties are involved in a project (client, consultant, contractor, and subcontractors), communication and coordination with other parties is a crucial factor in the timely completion of the project.

Effective communications avoid most delays. Proper communication and coordination channels between the various parties should be established during each phase of construction. Problems with communication may result in misunderstandings and, therefore, delays in the execution of the project. Finally, similar studies could be performed in specific types of construction projects, such as utility construction projects, pipeline construction projects, and dam construction projects. Detailed studies could be carried out to estimate the probability of delay (which is very important for project success and should be taken into account before the bidding stage) in construction projects by developing and utilizing the findings of this study.

\subsubsection{Recommendations to Client}

As client is the main party on the construction process, he/she is required to effectively participate in the improving the situation. The following advices are important for clients to ensure improvements in delivering projects on time:

1. More attention should be taken during the planning and design stages to ensure a well-defined scope and minimize any future changes in scope during the construction stage.

2. It is important to define the decision making process within the client organization and eliminate any tasks within that process that do not add any value "wastes".

3. Clients should have experienced and qualified personals that facilitate the construction process to avoid delays resulting from late approvals.

4. Clients are encouraged to select contractors and consultants carefully based on a combination of technical and financial criteria and not only based on the lowest price.

5. Clients are strongly advised to pay contractors on time as contractors are severely affected by delays in payments.

6. Clients should make sure the site is available for the contractor to start the construction activities and any restrictions such as local relocation should be tackled prior to construction.

\subsubsection{Recommendations to Contractor}

Contractors are also required to participate in the improvement revolution and the following actions are recommended:

1. Contractors should not bid for contracts unless they are confident of their capabilities to perform the work involved successfully.

2. Contractors are required to maintain a sound quality management and avoid any rework due to poor quality as it is costly and causes construction delays. 


\section{International Journal of Engineering Applied Sciences and Technology, 2019 Vol. 4, Issue 3, ISSN No. 2455-2143, Pages 470-491 \\ Published Online July 2019 in IJEAST (http://www.ijeast.com)}

3. Contractors should ensure the availability and the well management of all resources such as workforce, materials and equipment to avoid any work disruption.

4. All submittals should be submitted on the required time and in a proper way to avoid any construction delays due to difficulty of approving these submittals.

5. The contractor should focus on the development of the workforce and to maintain a permanent and cohesive team which is fully satisfied with the environment they are working in to ensure good communications and motivation.

\subsubsection{Recommendations to Consultant}

Consultants also share the responsibility in minimizing the construction delays although they are not highly accused of such delays. The followings are recommended for the consultants:

1. Consultants should work as a facilitator of the construction process and should change the strategy of chasing mistakes.

2. Consultants should react positively to contractors' inquiries and submittals and should also prepare any required drawings on the required time.

\section{REFERENCES}

(a) Sambasivan Murali and Soon Yau Wen (2007), Causes and effects of delays in Malaysian construction industry, International Journal of Project Management, (25), pp. 517526.

(b) Odeh A. M. and Battaineh H. T.(2002), Causes of Construction Delay: Traditional Contracts, International Journal of Project Management, (20), pp. 67-73.

(c) Al-Khalil M. and Al-Ghafly M.(1999), Important causes of delay in public utility projects in Saudi Arabia, Construction Management and Economics, 17(5), pp. 647-55.

(d) Frimpong Y, Oluwoye J. and Crawford L. (2003), Causes of delay and cost overruns in construction of groundwater projects in a developing countries; Ghana as a case study, International Journal of Project Management, (21), pp. 321326.

(e) Fugar F. D. K. and Agyakwah-Baah A. B.(2010), Delays in building construction projects in Ghana, Australasian Journal of Construction Economics and Building,10 (1/2), pp. 103-116.

(f) Chan D.W.M. and Kumaraswamy M. M. (1997), A comparative study of causes of time overruns in construction project, Hong Kong, International Journal of Project Management, 15 (1), pp. 55-63.

(g) Chan D. W. M. and Kumaraswamy M. M.(1996), the delay in Civil Engineering projects HongKong, 2 (3), pp. 1-8.

(h) Assaf S. A. and Al-Hejji S.(2006), Causes of delay in large construction projects, International Journal of Project Management, 24(4), pp. 349-57.

(i) Assaf S. A., Alkhalil M. and Al-Hazmi M.(1995), Causes of delay in large building construction projects, International Journal of Project Management, 11 (2), pp. 45-50. (j) Al Khalil M. and Ghaflu M. A.(1999), Delay in public utility projects in Saudi Arabia, International Journal of Project Management, 17(2), pp. 101-106.

(k) Al-Momani A.H.(2000), Construction delays: a quantitative analysis, International Journal of Project Management, 18(1), pp. 5-9.

(1) Kaming P.F., Olomolaiye P.O., Holt G.D. and Harris F.C. (1997), Factors influencing construction time and cost overruns on highrise projects in Indonesia, Journal of Construction Management and Economics, 15(1), pp. 83-94.

(1) Sugiharto A. and Hampson K.(2003), Identifying the important Causes of delays in building construction projects, In Proceedings the 9th east Asia-pacific Conference on Structural Engineering and Construction, Bali, Indonesia,

(m) Long L. H., Lee Y. D. and Lee J. Y. (2008), Delay and Cost Overruns in Vietnam Large Construction Projects: A Comparison with Other Selected Countries, Journal of Civil Engineering, 12(6), pp. 367-377.

(n) Mezher T. M. and Tawil W. (1998), Causes of delays in the construction industry in Lebanon.Engineering, Construction and Architectural Management, 5(3), pp. 252260.

(o) Arditiet (1985), Reasons for delays in public projects in Turkey, Construction and Architectural Management, 3(2), pp. 171-181.

(p) Semple C., Hartman F.T. and Jergeas G.(1994), Construction claims and disputes: Causes and cost time overruns, Journal of Construction Engineering and Management, 120(4), pp. 785-795.

(q) Shebob A., Dawood N., Shah R. K. (2012), Comparative study of delay factors in Libyan and the UK construction industry, Engineering, Construction and Architectural Management, 19(6), pp. 688-712.

(r) Acharya N. K., Lee Y. D. and Im H. M.(2006), Investigating delay factors in construction industry: A Korean perspective, Korean Journal of Construction Engineering and Management, (10), pp. 177-190.

(t)Ahmed S., Azher S., Castillo M. and Kappagantula P. (2002), Construction delays in Florida; an empirical study, Florida.

(s) Alaghbari W., Kadir M. R. A., Salim A. and Ernawati (2007), The significant factors causing delay of building construction projects in Malaysia, Engineering, Construction and Architectural Management Journal, 14 (2), pp. 192-206.

(t) Moura H and Teixeira J. C. (2007), Types of construction claims: a Portuguese survey. In:Boyd, D(Ed) Procs 23rd Annual ARCOM Conference, 3-5 September 2007, Belfast, UK, Association of Researchers in Construction Management, pp. 129-135.

(w)Abdullah M. R., Aziz A. A. A. and Rahman I. A. (2009), Causes of delay and its effects in large MARA construction project, International Journal of Integrated Engineering (Issue on Mechanical, Materials and Manufacturing Engineering. (x)Le-Hoai L., Lee Y. D. and Lee J. Y. (2008), Delay and Cost Overruns in Vietnam Large Construction Projects: A 


\section{International Journal of Engineering Applied Sciences and Technology, 2019 \\ Vol. 4, Issue 3, ISSN No. 2455-2143, Pages 470-491 \\ Published Online July 2019 in IJEAST (http://www.ijeast.com)}

Comparison with Other Selected Countries, KSCE Journal of Civil Engineering, 12(6), pp. 367-377.

(y) Gkritza K. and Labi S.(2008), Estimating cost discrepancies in highway contracts: Multistep econometric approach, Journal of Construction Engineering and Management, (134), pp. 953-962.

(z)El-Razak A.B.D, Bassioni M.E., H. A. and Mobarak A. M. (2008), Cause of Delay in Building Construction Projects in Egypt, Journal of Construction Engineering \& Management, 134 (11), pp. 831-841.

(aa) Al-Najjar A., and Kumaraswamy M. (2009), Delays and cost overruns in the construction projects in the Gaza Strip, Journal of Financial Management of Property and Construction, 14 (2), pp.126 - 151

(bb)Al-Khalil M. and Al-Ghafly M. (1999), Important causes of delay in public utility projects in SaudiArabi', Journal of Construction Management Economics, 17 (5), pp. 647-655.

(cc)Chan W. M. C. and Kumaraswamy M. M.(2002), Compressing construction durations: lessons learned from Hong Kong building projects, International Journal of Project Management, (20), pp. 23-35.

(dd)Kikwasi G. J. (2012), Causes and effects of delays and disruptions in construction projects in Tanzania, Australasian Journal of Construction Economics and Building, Conference Series,1(2), pp. 52-59.

(ee)Chan D. W. M and Kumaraswamy M. M.(1997), A comparative study of causes of time overruns in Hong Kong construction projects, International Journal of Project Management, 15 (1), pp. 55-63.

(ff)Faridi A. S. and El-Sayegh S. M.(2006), Significant factors causing delay in the UAE construction industry, Journal of Construction Management and Economics, 24 (11), pp. 11671176.

(gg)Koushki P. A., Al-Rashid K. and Kartam N.(2005), Delays and cost increases in the construction of private residential projects in Kuwait, Journal of Construction Management and Economics, 23 (3), pp. 285-294.

(hh)Meeampol S. and Ogunlan S. O.(2006), Factors affecting cost and time performance on highway construction projects: Evidence from Thailand, Journal of Financial Management of Property and Construction, 11 (1), pp.3-20.

(ii)Odeh A. M. and Battaineh H. T. (2002), Causes of construction delay: traditional contracts, International Journal of Project Management, (20), pp. 67-73.

(ji)Sambasivan M. and Soon Y. W. (2007), Causes and effects of delays in Malaysian construction industry, International Journal of Project Management,( 25), pp. 517526.

(kk)Tumi S. A. H., Omran A. and Pakir A. H. K. (2009), Causes of delay in construction Industry in Libya, The International Conference on Administration and Business, pp. 265-272.

(11)El-Razek A.B.D, Bassioni M.E, H.A. and Mobarak A. M. (2008), Causes of delays in building Construction projects in
Egypt, Journal of Construction Engineering and Management, 134 (11), pp. 831-841.

(mm)Ahmed S. M., Azhar S., Kappagntula P., Gollapudil D. (2003), Delays in construction: a brief study of Florida construction industry, Proceedings of the 39th Annual ASC Conference, Clemson University, Clemson, SC, pp. 257-66. (nn)Alaghbari W., Kadir M. R. A., Salim A., and Ernawati (2007), The significant factors causing delay of building construction projects in Malaysia, Engineering, Construction and Architectural Management, 14 (2), pp. 192-206.

(oo)Mohammed K. and Isah A.(2012), Causes of delay in Nigeria construction industry. Interdisciplinary Journal of Construction Research in Business, 4(2), 785-795.

(pp)Ayman H. and Al-Momani, (2000), Construction delays: a quantitative analysis, International Journal of Project Management, 18 (1), pp. 51-59. 